\title{
Gas-Phase Fragmentation Analysis of Nitro-Fatty Acids
}

\author{
Gustavo Bonacci, ${ }^{1}$ Eliana K. Asciutto, ${ }^{2}$ Steven R. Woodcock, ${ }^{1}$ Sonia R. Salvatore, ${ }^{1}$ \\ Bruce A. Freeman, ${ }^{1}$ Francisco J. Schopfer ${ }^{1}$ \\ ${ }^{1}$ Department of Pharmacology and Chemical Biology, University of Pittsburgh, E1340 BST, 200 Lothrop St., Pittsburgh, PA, \\ 15261, USA \\ ${ }^{2}$ Department of Chemistry and Biochemistry, Center for Computational Sciences, Duquesne University, Pittsburgh, PA, USA
}

\begin{abstract}
Nitro-fatty acids are electrophilic signaling mediators formed in increased amounts during inflammation by nitric oxide and nitrite-dependent redox reactions. A more rigorous characterization of endogenously-generated species requires additional understanding of their gas-phase induced fragmentation. Thus, collision induced dissociation (CID) of nitroalkane and nitroalkene groups in fatty acids were studied in the negative ion mode to provide mass spectrometric tools for their structural characterization. Fragmentation of nitroalkanes occurred mainly through loss of the $\mathrm{NO}_{2}{ }^{-}$anion or neutral loss of $\mathrm{HNO}_{2}$. The CID of nitroalkenes proceeds via a more complex cyclization, followed by fragmentation to nitrile and aldehyde products. Gas-phase fragmentation of nitroalkene functional groups with additional $\mathrm{y}$ or $\delta$ unsaturation occurred through a multiple step cyclization reaction process, leading to 5 and 6 member ring heterocyclic products and carbon chain fragmentation. Cyclization products were not obtained during nitroalkane fragmentation, highlighting the role of double bond $\pi$ electrons during $\mathrm{NO}_{2}^{-}$rearrangements, stabilization and heterocycle formation. The proposed structures, mechanisms and products of fragmentation are supported by analysis of ${ }^{13} \mathrm{C}$ and ${ }^{15} \mathrm{~N}$ labeled parent molecules, 6 different nitroalkene positional isomers, 6 nitroalkane positional isomers, accurate mass determinations at high resolution and quantum mechanics calculations. Multiple key diagnostic ion fragments were obtained through this analysis, allowing for the precise placement of double bonds and sites of fatty acid nitration, thus supporting an ability to predict nitro positions in biological samples.
\end{abstract}

Key words: Nitrated fatty acid, $\mathrm{LNO}_{2}, \mathrm{OA}-\mathrm{NO}_{2}$, Nitroalkene, Nitroalkane, Nitro-oleic acid, Nitrolinoleic acid, $\mathrm{NO}_{2}-\mathrm{FA}$

Abbreviations: CID Collision induced dissociation; $\mathrm{NO}_{2}-\mathrm{FA}$ Nitro-fatty acids; $\mathrm{NO}_{2}-\mathrm{SA}$ nitrated stearic acid; $\mathrm{NO}_{2}-\mathrm{OA}$ nitrated oleic acid; $\mathrm{NO}_{2}$-LA nitrated linoleic acid; 9- $\mathrm{NO}_{2}-\mathrm{OA}$ 9-nitrooctadeca-9-enoic acid; $10-\mathrm{NO}_{2}-\mathrm{OA}$ 10-nitro-octadeca-9-enoic acid; 9- $\mathrm{NO}_{2}$-LA 9-nitro-octadeca9,12-dienoic acid; $10-\mathrm{NO}_{2}$-LA 10-nitro-octadeca-9,12-dienoic acid; 12- $\mathrm{NO}_{2}$-LA 12-nitrooctadeca-9,12-dienoic acid; 13- $\mathrm{NO}_{2}$-LA 13-nitro-octadeca-9,12-dienoic acid; 9- $\mathrm{NO}_{2}-\mathrm{SA}$ 9nitro-octadecanoic acid; $10-\mathrm{NO}_{2}-\mathrm{SA}$ 10-nitro-octadecanoic acid; ZPE Zero point vibrational energies; LOD limit of detection and LOQ limit of quantification

Electronic supplementary material The online version of this article (doi:10.1007/s13361-011-0185-x) contains supplementary material, which is available to authorized users.

Correspondence to: Bruce J. Freeman; e-mail: freerad@pitt.edu, Francisco J. Schopfer;e-mail: fjs2@pitt.edu

\section{Introduction}

Vitro-fatty acids $\left(\mathrm{NO}_{2}-\mathrm{FA}\right)$ are ubiquitous molecules 1 formed upon the nitration of unsaturated fatty acids

Received: 22 February 2011

Revised: 1 June 2011

Accepted: 1 June 2011

Published online: 13 July 2011 
by nitric oxide and nitrite-derived species, predominantly nitrogen dioxide $[1,2]$. Following initial reports of in vitro formation, $\mathrm{NO}_{2}$-FA were found to occur under physiological conditions in animal and human blood, urine and tissues [3-8] and to mediate a variety of signaling mechanisms [9-11].

The detection of biologically-active fatty acid metabolites was initially performed by GC-MS, which added lengthy sample derivatization steps to protect labile groups and make fatty acid derivatives more volatile. Although some biologically active lipid-derived species are still being measured by GC-MS (i.e. isoprostanes [12]), most of the protocols migrated to LC-ESI-MS methods because of shorter sample work-up times and increased preservation of unstable and reactive products. In particular, electrophilic $\mathrm{NO}_{2}-\mathrm{FA}$ decay at accelerated rates under the basic conditions of some derivatization reactions, while acid-catalyzed nitration of native fatty acid occurs at low $\mathrm{pH}$ in the presence of nitrite, generating artifactual nitrated fatty acids. These issues significantly complicate the value of GC-MS-based sample analyses. The "soft" ionization of ESI-based procedures provides a more precise and sensitive approach for analyzing samples using triple quadrupole and linear ion trap mass spectrometers. Because of its versatility, LC-ESI-MS has been the preferred method for the detection, analysis and quantification of $\mathrm{NO}_{2}$-FA. In this regard, $\mathrm{NO}_{2}-\mathrm{FA}$ analysis has been performed in negative ion mode using tandem mass spectrometry, with collision induced dissociation (CID) energies that maximize the charged and neutral losses of $\mathrm{NO}_{2}{ }^{-}$and $\mathrm{HNO}_{2}(35 \mathrm{eV})$. This approach does not provide data about regioisomer composition or distribution [3, 4, 13, 14]. Although this technique is of value for quantification, additional structural information about specific regioisomer distribution is lost. Thus, structural confirmation of biological samples has relied on the synthesis and comparison to ${ }^{13} \mathrm{C}$ or ${ }^{15} \mathrm{~N}$ labeled internal standards [4, 15-17], resulting in a number of limitations. First, no structural differences are observed upon fragmenting nitroalkenes versus nitroalkanes, since both yields the same $46 \mathrm{Da}$ product ion. This is of relevance, since in rodents and humans, nitroalkanes are a metabolite of nitroalkenes [14] and the signaling actions of nitroalkenes differ widely from nitroalkanes [9, 15, 18, 19]. In this vein, different nitroalkene regioisomers have specific peroxisome-proliferator activated receptor $\gamma(\operatorname{PPAR} \gamma)$-mediated signaling actions, highlighting the need for mass spectrometric methods that aid in their elucidation [20, 21].

Nitro-fatty acids are ideal candidates for LC-ESI-MS characterization and quantification because of the ease of ionization of the carboxylic acid and facile loss of characteristic $\mathrm{NO}_{2}$ group. Characterization of vicinal nitro-hydroxy fatty acids, a product of nitroalkene hydration, has been simplified by the electron withdrawing properties of hydroxyl $(\mathrm{OH})$ groups, allowing for precise prediction of fragmentation products [3, 22]. The structural characterization and fragmentation analysis of nitroalkenes was attempted using collision induced fragmentation without conclusive results [23]. So far, the strongest mass spectrometric structural analysis of $\mathrm{NO}_{2}-\mathrm{FA}$ is based on $\mathrm{Li}^{+}$ adduction, that helps direct fragmentation and analysis of products in the positive ion mode [24]. Although this can provide revealing structural information, poor sensitivity induces limitations in biological sample analysis.

CID is a fragmentation technique based on energizing an ion by collision with a neutral gas (helium for ion trap and nitrogen for triple quadrupole spectrometers). Upon gas collisions with the ions of interest, translational energy is transferred as vibrational and rotational energy into the ion, which induces bond dissociation. This fragmentation is generally heterolytic and predominantly generates evenelectron ion pairs, although radical ions are formed under some circumstances [25]. While rules to explain and predict fragmentation patterns have been established, they are not consistently reliable for unambiguous identification of unknown compounds [26]. This motivated better understanding of the fragmentation of nitroalkenes to provide the structural insight needed for biological sample analysis. Herein we characterize the fragmentation pathways of $\mathrm{NO}_{2}$-FA containing the following groups: nitroalkanes, nitroalkane-alkenes, nitroalkenes and bis-allylic nitroalkenes. This study defines an unprecedented gas-phase fragmentation pathway for nitroalkenes involving remote oxygen transfer, supported by the use of ${ }^{13} \mathrm{C}$ labeled standards and ${ }^{15} \mathrm{~N}$ nitroalkenes. Fragmentation ions were characterized in the negative ion mode using two mass spectrometers (triple quadrupole and linear ion trap) and the proposed fragmentation pathways were analyzed by semiempirical and quantum mechanics calculations. These findings thus permit more precise prediction of fragment ions following $\mathrm{MS} / \mathrm{MS}$ of unknown $\mathrm{NO}_{2}$-FA and their metabolites.

\section{Materials and Methods}

Solvents were obtained from Burdick and Jackson. All other materials and reagents were obtained from Sigma-Aldrich (St. Louis, MO, USA). All $\mathrm{NO}_{2}$-FA were synthesized as previously $[4,27]$. Nitroalkanes were obtained by selectively reducing nitroalkenes to the corresponding nitroalkane using $\mathrm{NaBH}_{4}$.

\section{Chromatography}

Isomers were separated previous to mass spectrometry analysis using a C18 reverse phase column $(2 \times 150 \mathrm{~mm}, 3$ $\mu \mathrm{m}$ particle; Phenomenex ) at a $250 \mu \mathrm{L} / \mathrm{min}$ flow rate. Nitrated fatty acids were injected at $65 \%$ A $\left(\mathrm{H}_{2} \mathrm{O}+0.1 \%\right.$ acetic acid), the gradient was held for $3 \mathrm{~min}$, and then the gradient was ramped to $20 \% \mathrm{~A}$ in $45 \mathrm{~min}$. The column was washed at $100 \%$ B (acetonitrile $+0.1 \%$ acetic acid), held for $4 \mathrm{~min}$, and switched back to initial conditions for reequilibration for $5 \mathrm{~min}$. 


\section{Mass Spectrometry}

The CID spectra were recorded using a LTQ Velos Orbitrap equipped with a HESI II electrospray source. The following parameters were used: source temperature $400{ }^{\circ} \mathrm{C}$, capillary temperature $360^{\circ} \mathrm{C}$, sheath gas flow 30 , auxiliary gas flow 15 , sweep gas flow 2 , source voltage $-3.3 \mathrm{kV}$, S-lens RF level $44(\%)$. The instrument FT-mode was calibrated using the manufacturers recommended calibration solution with the addition of malic acid as a low $\mathrm{m} / \mathrm{z}$ calibration point in the negative ion mode.

\section{Fragmentation Yield Calculation}

Areas under the curve for all the reported specific MRM transitions were calculated at different concentrations in the presence of internal standard. A standard curve for each $\mathrm{NO}_{2}$-OA and $\mathrm{NO}_{2}$-LA isomer was created for each specific transition by plotting area ratios (analyte specific MRM peak area/internal standard peak area) against concentration ratio (analyte concentration/internal standard concentration) and slopes were calculated. Slopes were used as an index of detection efficiency for each particular product ion.

\section{Computational Approaches}

To test structural candidate fragments, the structures were built using the MOE program [28]. Energies of all candidate molecules were calculated using the semiempirical PM3 method [29]. Selected candidates were fully investigated using ab initio calculations. The structure of each fragment was optimized using Gaussian 09 [30] at the B3LYP level of theory, with the triple split valence $6-311 \mathrm{G}$ basis set. Zero point vibrational energies (ZPE) corrections were also calculated at the same level of theory.

\section{Results and Discussion}

The first approach to structural elucidation by mass spectrometry was to study the CID-induced fragmentation spectra of the nitro-oleic acid $\left(\mathrm{NO}_{2}-\mathrm{OA}\right)$ regioisomers 9-nitrooctadeca-9-enoic acid (9- $\left.\mathrm{NO}_{2}-\mathrm{OA}\right)$ and 10-nitro-octadeca-9enoic acid $\left(10-\mathrm{NO}_{2}-\mathrm{OA}\right)$.

\section{Negative Ion Mode CID-MS/MS of 9- $\mathrm{NO}_{2}-\mathrm{OA}$, and $10-\mathrm{NO}_{2}-\mathrm{OA}$}

The ESI-MS-MS mass spectrum of the 9- $\mathrm{NO}_{2}-\mathrm{OA}[\mathrm{M}-\mathrm{H}]^{-}$ in negative ion mode and at collision energies of $-35 \mathrm{eV}$ (using a 4000 Qtrap tandem mass spectrometer, Applied Biosystems) showed the formation of the following ions at $m / z 308.2\left[\mathrm{M}-\mathrm{H}_{2} \mathrm{O}\right]^{-}, 290.2\left[\mathrm{M}-2 \mathrm{H}_{2} \mathrm{O}\right]^{-}, 279.2[\mathrm{M}-$ $\left.\mathrm{HNO}_{2}\right]^{-}, 246.2\left[\mathrm{M}-2 \mathrm{H}_{2} \mathrm{O}-\mathrm{CO}_{2}\right]^{-}$(Figure 1), as previously [3]. Similar high collision energies have been previously used in tandem mass spectrometers for the quantification of nitro-fatty acids $[3,6,13,14,31]$, for sensitivity optimiza- tion of MRM transitions 324.2/46, and 324.2/279.2. The $\mathrm{MS}^{3}$ analysis of the aforementioned product ions was similar for the $9-\mathrm{NO}_{2}-\mathrm{OA}$ and the $10-\mathrm{NO}_{2}-\mathrm{OA}$ isomers and was used to evaluate the charge site and charge mobility during the fragmentation process. The $\mathrm{MS}^{3}$ fragmentation of 326.3 $m / z \rightarrow 308.2 \mathrm{~m} / z$ resulted in loss of $\mathrm{H}_{2} \mathrm{O}(\mathrm{m} / \mathrm{z} 290.2), \mathrm{CO}_{2}$ $\left(\mathrm{m} / z\right.$ 264.2) and $\mathrm{CO}_{2}+\mathrm{H}_{2} \mathrm{O}\left(\mathrm{m} / z\right.$ 246.2). $\mathrm{MS}^{3}$ fragmentation of $326.3 \mathrm{~m} / z \rightarrow 279.2 \mathrm{~m} / \mathrm{z}$ resulted in loss of $\mathrm{H}_{2} \mathrm{O}(\mathrm{m} / \mathrm{z} 261.2)$ and loss of $\mathrm{CO}_{2}(\mathrm{~m} / \mathrm{z} 235.1)$; $\mathrm{MS}^{3}$ fragmentation of $\mathrm{NO}_{2^{-}}$ $\left[{ }^{13} \mathrm{C}_{18}\right] \mathrm{OA}$ for the following product ions: $344.3 \mathrm{~m} / \mathrm{z} \rightarrow 326.2$ $\mathrm{m} / \mathrm{z}$ resulted in loss of $\mathrm{H}_{2} \mathrm{O}(\mathrm{m} / \mathrm{z} 308.2), \mathrm{HNO}_{2}(\mathrm{~m} / \mathrm{z} 279.2)$ and $\mathrm{HNO}_{2}+\mathrm{H}_{2} \mathrm{O}(\mathrm{m} / \mathrm{z} 261.2)$, and $344.3 \mathrm{~m} / \mathrm{z} \rightarrow 308.2 \mathrm{~m} / \mathrm{z}$ for loss of ${ }^{13} \mathrm{CO}_{2}(\mathrm{~m} / \mathrm{z} 263.2)$. Despite a high sensitivity, no specific structural information can be extracted from these product ions. Lowering the collision energy in the triple quadrupole $\mathrm{MS}$ to the $15-20 \mathrm{eV}$ range results in the appearance of additional ions that are not apparent at higher collision energies. This motivated characterization of these ions using a high resolution ion trap mass spectrometer in order to gain structural information and to obtain $\mathrm{MS}^{3}$ fragmentation spectra. Unlike triple quadrupole-MS at low collision energies $(17 \mathrm{eV})$, ion traps favor non-chain-breaking products ions $\left(\mathrm{HNO}_{2}, \mathrm{H}_{2} \mathrm{O}\right.$, and $\mathrm{CO}_{2}$ losses) over chainbreaking fragmentations resulting in a lower yield of overall product ions containing structural information.

\section{9- $\mathrm{NO}_{2}-\mathrm{OA}$}

Fragmentation of 9- $\mathrm{NO}_{2}-\mathrm{OA}$ results in formation of an ion at $\mathrm{m} / \mathrm{z} 168.1$ fragment (Figure 1A and Scheme 1A). Its structure was confirmed by accurate mass measurement, showing a mass of 168.1026 that corresponds to an elemental composition of $\left[\mathrm{C}_{9} \mathrm{H}_{14} \mathrm{O}_{2} \mathrm{~N}\right]^{-}$. This was further confirmed by the fragmentation of $9-\mathrm{NO}_{2}-\left[{ }^{13} \mathrm{C}_{18}\right] \mathrm{OA}$, which gave an ion with a mass of 177.1326 , corresponding to $\left[{ }^{13} \mathrm{C}_{9} \mathrm{H}_{14} \mathrm{O}_{2} \mathrm{~N}\right]^{-}$ (Figure 1B). $\mathrm{MS}^{3}$ fragmentation of the $326.2 \mathrm{~m} / \mathrm{z} \rightarrow 168.1 \mathrm{~m} / \mathrm{z}$ ion resulted in the loss of $\mathrm{CO}_{2}(\mathrm{~m} / \mathrm{z}$ 124.1132), confirming that the 168.1 fragment consisted of nine carbons including the carboxylate end of the molecule and no oxygen atoms being lost from the carboxylic acid during the initial chain fragmentation, while both oxygen atoms from the nitro group were transferred to neutral products ions.

\section{$10-\mathrm{NO}_{2}-\mathrm{OA}$}

The $\mathrm{MS}^{2}$ analysis of $10-\mathrm{NO}_{2}-\mathrm{OA}$ shows the formation of a specific ion at $\mathrm{m} / \mathrm{z} 169.0864$, with a calculated atomic composition of $\left[\mathrm{C}_{9} \mathrm{H}_{13} \mathrm{O}_{3}\right]^{-}$(Figure 1C, Scheme 1B). Further $\mathrm{MS}^{3}$ analysis of this fragment shows a loss of $\mathrm{CO}_{2}(\mathrm{~m} / \mathrm{z}$ 125.0977, corresponding to a molecular composition of $\left[\mathrm{C}_{8} \mathrm{H}_{13} \mathrm{O}\right]^{-}$with $\mathrm{m} / z$ 125.0961), confirming that this product ion contains the carboxylic acid end. Fragmentation of $10-\mathrm{NO}_{2}-$ $\left[{ }^{13} \mathrm{C}_{18}\right] \mathrm{OA}$, resulted in the formation of the expected 178.1167 fragment corresponding to $\left[{ }^{13} \mathrm{C}_{9} \mathrm{H}_{13} \mathrm{O}_{3}\right]^{-}$(Figure 1D). 

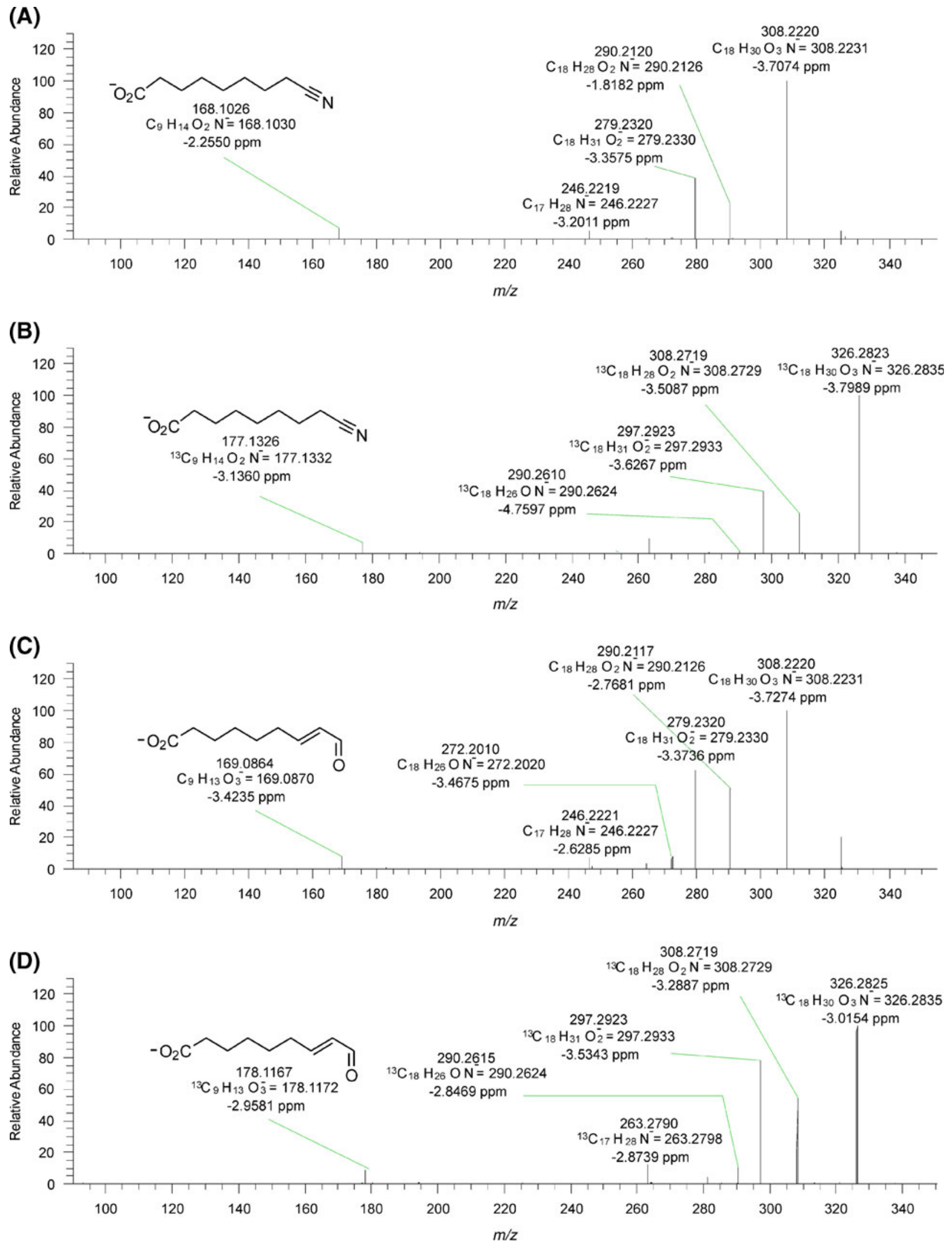

Figure 1. Product ion spectra of $[\mathrm{M}-\mathrm{H}]^{-}$ions of $\mathrm{m} / \mathrm{z} 326.3$ and 344.3 corresponding to $\mathrm{NO}_{2}-\mathrm{OA}$ and $\mathrm{NO}_{2}-\left[{ }^{13} \mathrm{C}_{18}\right] \mathrm{OA}$, respectively. (A) 9- $\mathrm{NO}_{2}-\mathrm{OA}$, (B) 9- $\mathrm{NO}_{2}-\left[{ }^{13} \mathrm{C}_{18}\right] \mathrm{OA}$, (C) 10- $\mathrm{NO}_{2}-\mathrm{OA}$, (D) $10-\mathrm{NO}_{2}-\left[{ }^{13} \mathrm{C}_{18}\right] \mathrm{OA}$ recorded at a collision energy setting of $35 \mathrm{eV}$ using a hybrid FT mass spectrometer 


\section{$\mathrm{NO}_{2}-\mathrm{OA}$ Fragmentation Mechanism}

The proposed mechanism for the carbon chain fragmentation directed by the nitroalkene in the absence of neighboring double bonds is shown for 9- $\mathrm{NO}_{2}-\mathrm{OA}$ (Scheme 2). The steps proposed begin with initial rearrangement of the nitro group (see Scheme 2 sidebar), possibly via an unstable threemember dioxaziridine ring, to form a peroxynitroso species, followed by a 1,3-cycloaddition of this moiety with the carbon-carbon double bond to form a 1,2,3-dioxazole intermediate. This pentacycle is labile to intramolecular retro-1,3-cycloaddition Criegee-like fragmentation reaction to form a nitrile group $(\mathrm{C} \equiv \mathrm{N})$ and an unstable carbonyl peroxide zwitterion $\left(\mathrm{C}=\mathrm{O}-\mathrm{O}^{-}\right)$that rapidly loses water through proton transfer to form the corresponding $\alpha-, \beta$ unsaturated nonyl aldehyde $(\mathrm{C}=\mathrm{O})$. The same mechanism operating symmetrically describes the $10-\mathrm{NO}_{2}-\mathrm{OA}$ fragmentation pathway (Scheme 1B). The nitroalkene is sufficiently

(A)

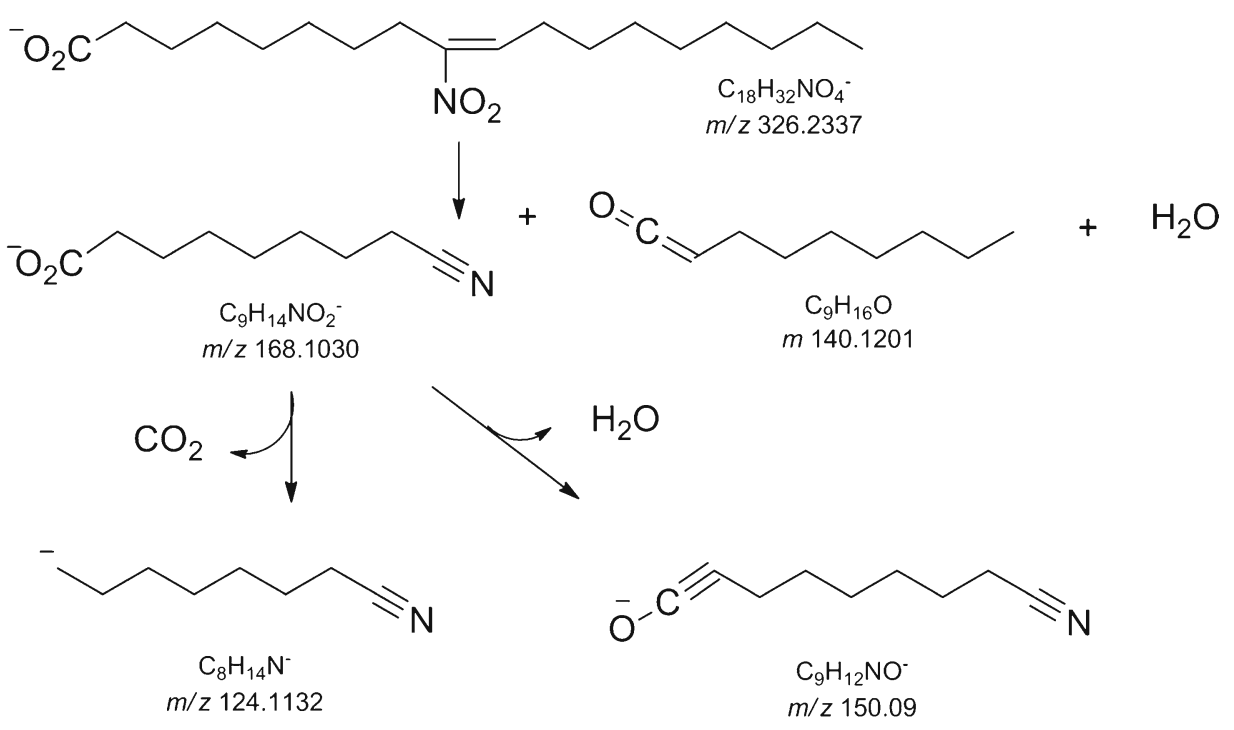

(B)

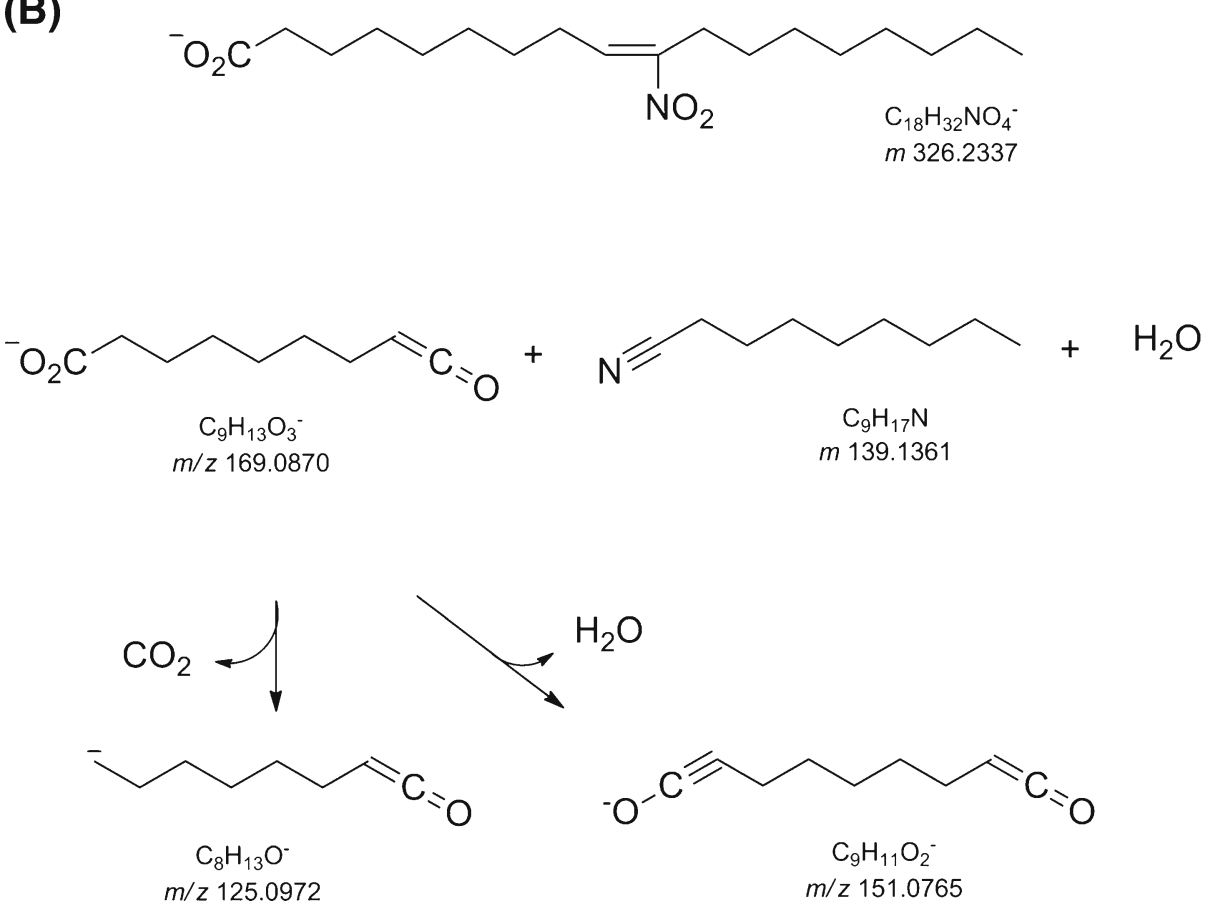

Scheme 1. Fragmentation products of $9-\mathrm{NO}_{2}-\mathrm{OA}$ and $10-\mathrm{NO}_{2}-\mathrm{OA}$. (A) Fragmentation of 9-NO $\mathrm{N}_{2}-\mathrm{OA}$ results in a characteristic ion with $m / z$ 168.1, which can be further fragmented to elicit neutral losses of $\mathrm{H}_{2} \mathrm{O}$ and $\mathrm{CO}_{2}$. (B) Fragmentation of $10-\mathrm{NO}_{2}-\mathrm{OA}$ results in a product ion $\mathrm{m} / z$ 169.1, which displays losses of $\mathrm{H}_{2} \mathrm{O}$ and $\mathrm{CO}_{2}$ in $\mathrm{MS}^{3}$ fragmentations 


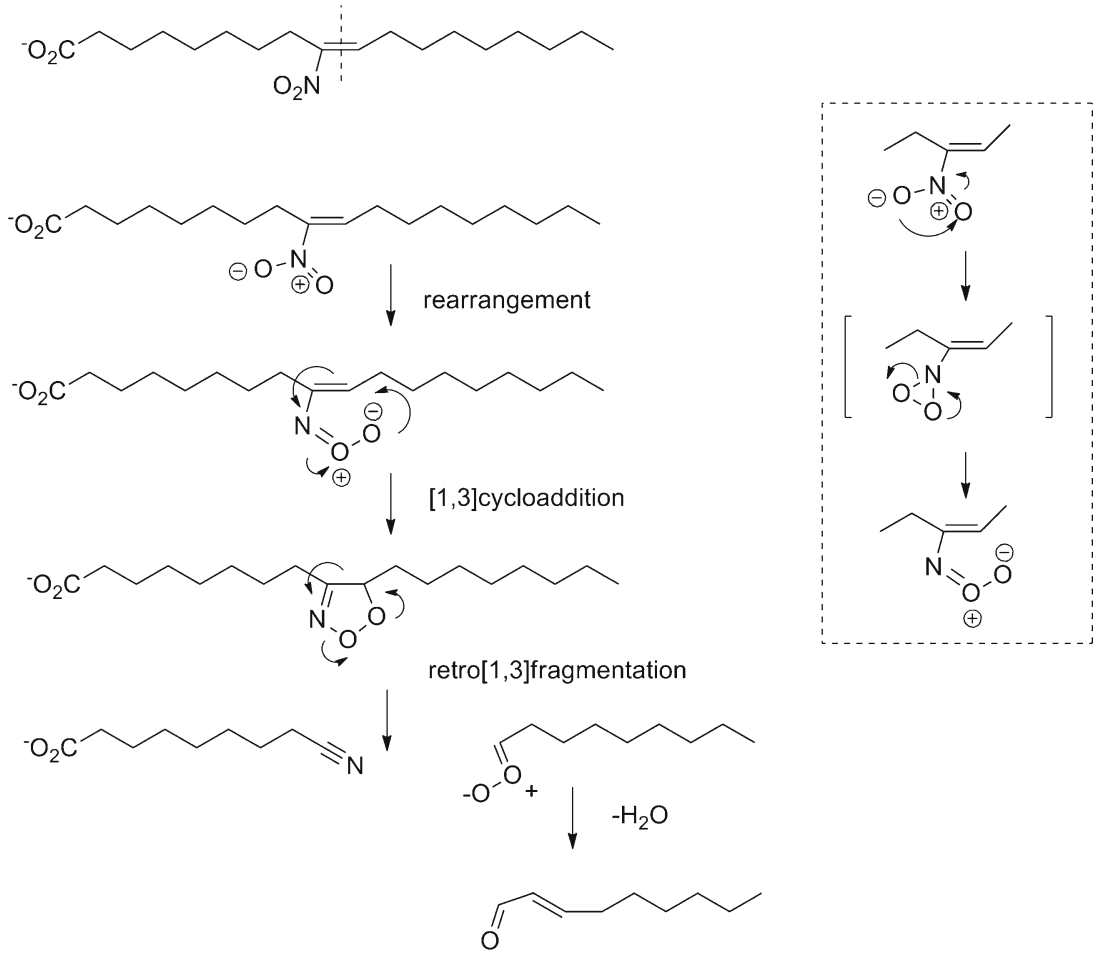

Scheme 2. Proposed fragmentation mechanism of $9-\mathrm{NO}_{2}-\mathrm{OA}$. The fragmentation proceeds through a series of steps that include rearrangement, 1,3-cycloaddition and a final retro-1,3-fragmentation to a nitrile and corresponding unsaturated aldehyde. Sidebar: potential rearrangement of nitro group to hypothesized peroxynitroso intermediate

equidistant from both the methyl and carboxylate termini, thus it is assumed that there are no significant directing effects or interactions.

\section{Negative Ion Mode CID-MS/MS of $\mathrm{NO}_{2}-\mathrm{LA}$}

Similar to $\mathrm{NO}_{2}-\mathrm{OA}$, the $\mathrm{MS}^{2}$ spectra of $\mathrm{NO}_{2}$-LA $(\mathrm{m} / \mathrm{z} 324.2)$ at high collision energies $(-35 \mathrm{eV})$ showed the main neutral losses of $\mathrm{H}_{2} \mathrm{O}, 2 \mathrm{H}_{2} \mathrm{O}, \mathrm{HNO}_{2}$, and minor losses of $3 \mathrm{H}_{2} \mathrm{O}$, $\mathrm{H}_{2} \mathrm{O}+\mathrm{CO}_{2}$ and $2 \mathrm{H}_{2} \mathrm{O}+\mathrm{CO}_{2}$ resulting in the following product ions at $\mathrm{m} / \mathrm{z} 306.2,288.2,277.2,270.2,262.2,244.2$ respectively (Figure 2A, C, and Figure $3 \mathrm{~A}, \mathrm{C}$ ). The main losses of $\mathrm{H}_{2} \mathrm{O}$ derive, as for $\mathrm{NO}_{2}-\mathrm{OA}$, from condensation reactions involving the oxygen atoms present in the $\mathrm{NO}_{2}$ group. This is further confirmed by the $\mathrm{MS}^{3}$ analysis of $324.2 \mathrm{~m} / \mathrm{z} \rightarrow 306.2 \mathrm{~m} / \mathrm{z}$ and $\rightarrow 288.2 \mathrm{~m} / \mathrm{z}$ that result in the main loss of $\mathrm{CO}_{2}$, indicating an intact carboxylate group after the initial two consecutive water losses, thus representing a non-chain-breaking fragmentation pathway similar to $\mathrm{NO}_{2}$-OA. Fragmentation of $\mathrm{NO}_{2}-\left[{ }^{13} \mathrm{C}_{18}\right]$ LA displayed same neutral losses observed for $\mathrm{NO}_{2}$-LA as follows: $324.3 \mathrm{~m} / \mathrm{z}$ $\left[\mathrm{M}-\mathrm{H}_{2} \mathrm{O}\right]^{-}, 306.2 \mathrm{~m} / \mathrm{z}\left[\mathrm{M}-2 \mathrm{H}_{2} \mathrm{O}\right]^{-}, 288.2 \mathrm{~m} / \mathrm{z}[\mathrm{M}-$ $\left.3 \mathrm{H}_{2} \mathrm{O}\right]^{-}, 295.2 \mathrm{~m} / \mathrm{z}\left[\mathrm{M}-\mathrm{HNO}_{2}\right]^{-}, 279.2 \mathrm{~m} / z\left[\mathrm{M}-\mathrm{H}_{2} \mathrm{O}-\right.$ $\left.{ }^{13} \mathrm{CO}_{2}\right]^{-}, 261.2 \mathrm{~m} / \mathrm{z}\left[\mathrm{M}-2 \mathrm{H}_{2} \mathrm{O}-{ }^{13} \mathrm{CO}_{2}\right]^{-}$(Figure 2B, D, and Figure $3 \mathrm{~B}, \mathrm{D})$. Again, the $\mathrm{MS}^{3}$ spectra of the 306.3 and 288.2 ions confirmed the preferential condensation reaction involving the oxygen atoms of the $\mathrm{NO}_{2}$ group since the main $\mathrm{MS}^{3}$ fragment showed loss of ${ }^{13} \mathrm{CO}_{2}$ group.

\section{Fragment Characterization of $\mathrm{NO}_{2}-\mathrm{LA}$}

9-NO ${ }_{2}$-LA: Using an online HPLC, the mixture of 4 $\mathrm{NO}_{2}$-LA positional regioisomers $\left(9-\mathrm{NO}_{2}-\mathrm{LA}, 10-\mathrm{NO}_{2}-\mathrm{LA}\right.$, $12-\mathrm{NO}_{2}-\mathrm{LA}$, and 13- $\left.\mathrm{NO}_{2}-\mathrm{LA}\right)$ was chromatographically resolved. $\mathrm{NO}_{2}$-LA positional isomers have been previously described and confirmed by NMR [4, 32]. The CID fragmentation of $9-\mathrm{NO}_{2}$-LA resulted in the formation of three main product ions containing structural information with $\mathrm{m} / \mathrm{z}$ values of 168.1, 210.1, and 224.1 (Figure 2A). Thus, the presence of a bis-allylic interrupted diene favored additional fragmentation pathways (formation of 210.1 and $224.1 \mathrm{~m} / z$ product ions), not observed for $9-\mathrm{NO}_{2}-\mathrm{OA}$. The proximity of an electron-rich $\pi$ bond to the highly electron withdrawing nitroalkene and the nitro group itself make possible a rich array of productive mechanisms. The mechanistic pathway leading to the formation of an ion with $\mathrm{m} / z 168.1$ is common between $9-\mathrm{NO}_{2}-\mathrm{OA}$ and $9-\mathrm{NO}_{2}-$ LA and corresponds to a cleavage of the $\mathrm{C} 9-\mathrm{C} 10$ double bond, with a net transfer of one or both oxygens from the $\mathrm{NO}_{2}$ group to its $\beta$ carbon (C10) (Schemes 1, 2, and 3A).

As a first approach to understanding the fragmentation mechanism, we investigated structural candidates for the ion $\mathrm{m} / \mathrm{z} 168.1$ (168.1026, molecular composition $\left[\mathrm{C}_{9} \mathrm{H}_{14} \mathrm{O}_{2} \mathrm{~N}\right]^{-}$). The candidate products, displayed in Supplementary Scheme 1, were proposed based on the molecular composition and structure of $9-\mathrm{NO}_{2}-\mathrm{LA}$. Relative energies of predicted fragments were calculated using the PM3 semi- 
(A)

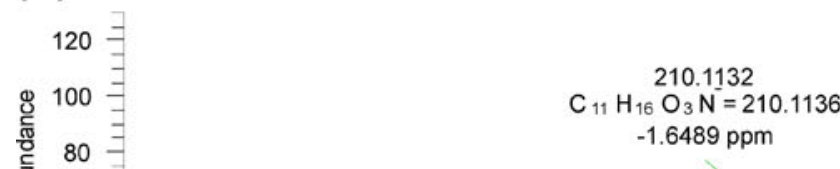

277.2167

$\mathrm{C}_{18} \mathrm{H}_{29} \mathrm{O}_{2}^{-}=277.2173 \quad 306.2070$

$-2.1109 \mathrm{ppm} \quad \mathrm{C}_{18} \mathrm{H}_{28} \mathrm{O}_{3} \mathrm{~N}^{-}=306.2075$

$-1.6353 \mathrm{ppm}$

$\mathrm{C}_{9} \mathrm{H}_{14} \mathrm{O}_{2} \mathrm{~N}^{-}=168.1030$

224.1289

$\mathrm{C}_{12} \mathrm{H}_{18} \mathrm{O}_{3} \mathrm{~N}=224.1292$

$-1.3172 \mathrm{ppm}$
$\mathrm{C}_{18} \mathrm{H}_{26} \mathrm{O}_{2} \mathrm{~N}=288.1969$

$-0.4223 \mathrm{ppm}$

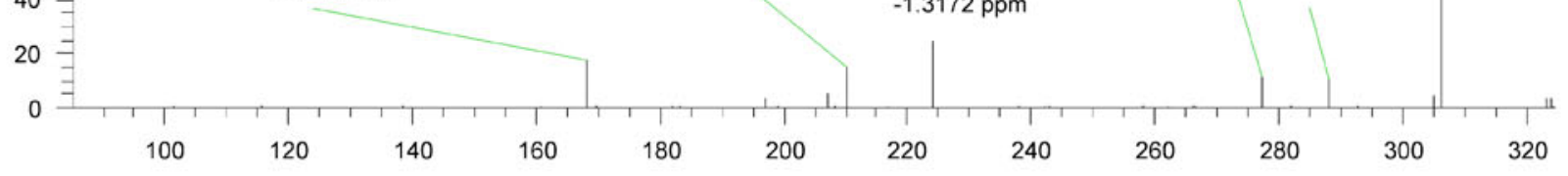

$m / z$

(B)

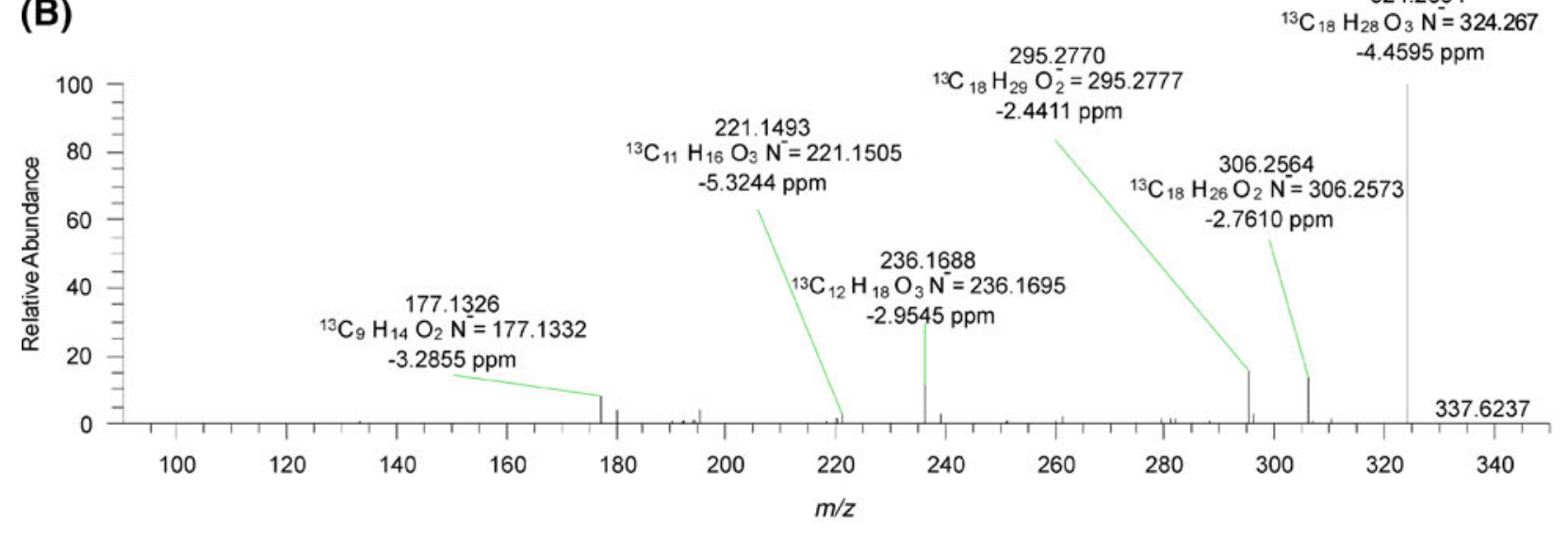

(C)

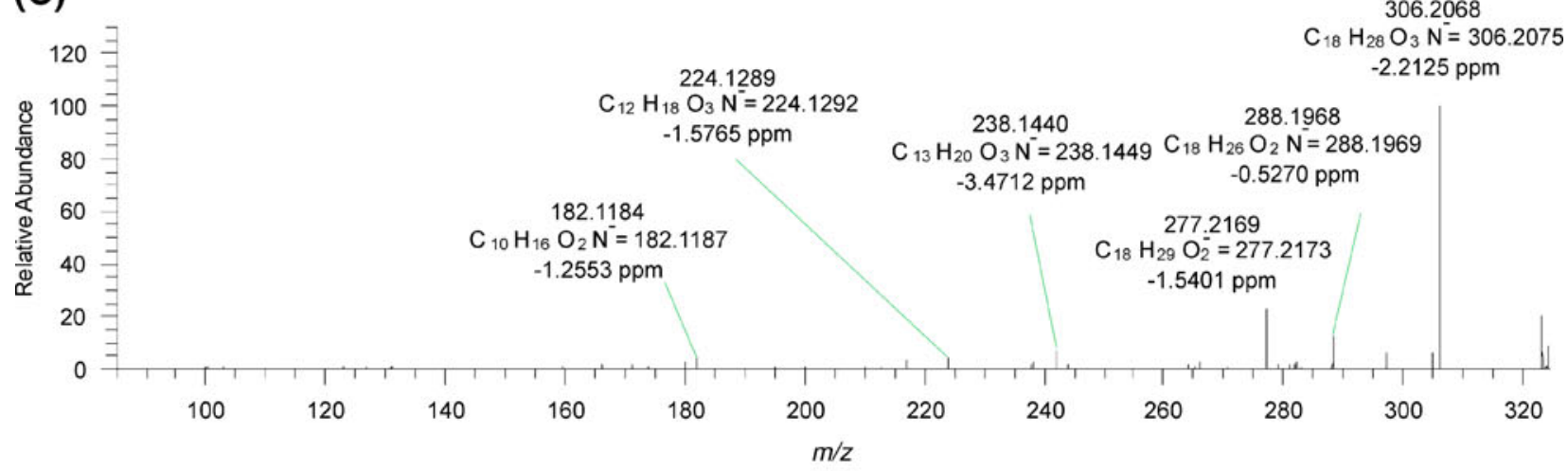

(D)

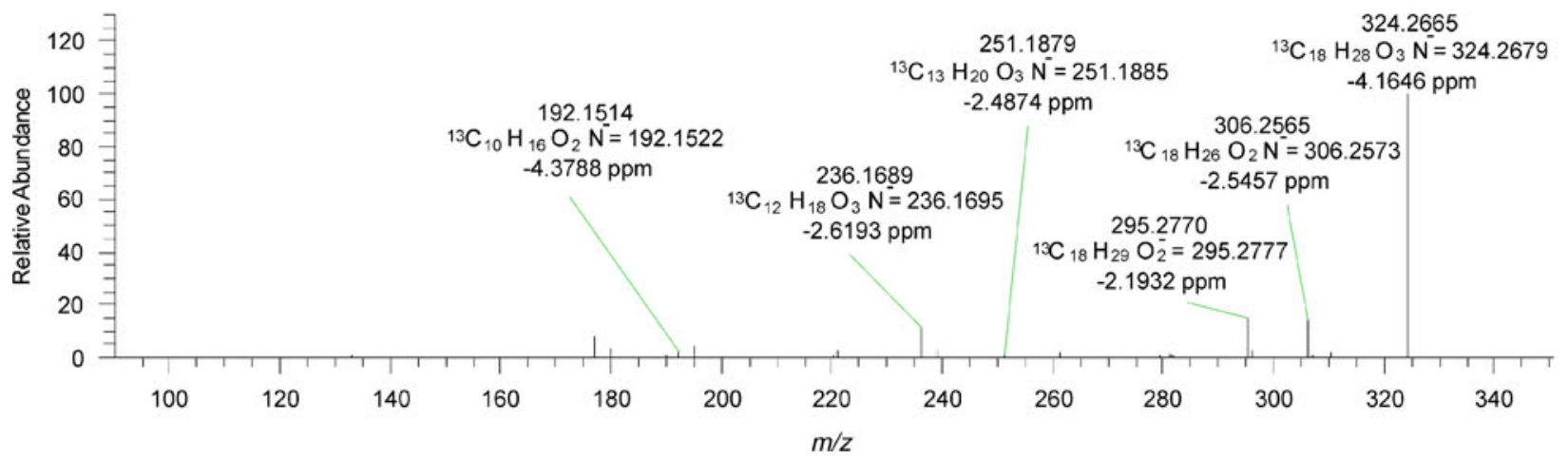

Figure 2. Product ion spectra of $\left[\mathrm{M}-\mathrm{H}^{-}\right.$ions of $\mathrm{m} / \mathrm{z} 324.2$ and 342.3 corresponding to $\mathrm{NO}_{2}-\mathrm{LA}$ and $\mathrm{NO}_{2}-\left[{ }^{13} \mathrm{C}_{18}\right] \mathrm{LA}$ respectively. (A) 9- $\mathrm{NO}_{2}-\mathrm{LA},\left(\right.$ B) $9-\mathrm{NO}_{2}-\left[{ }^{13} \mathrm{C}_{18}\right] \mathrm{LA}$, (C) $10-\mathrm{NO}_{2}-\mathrm{LA}$, (D) $10-\mathrm{NO}_{2}-\left[{ }^{13} \mathrm{C}_{18}\right] \mathrm{LA}$ recorded at a collision energy setting of $35 \mathrm{eV}$ using a hybrid FT mass spectrometer 
(A)

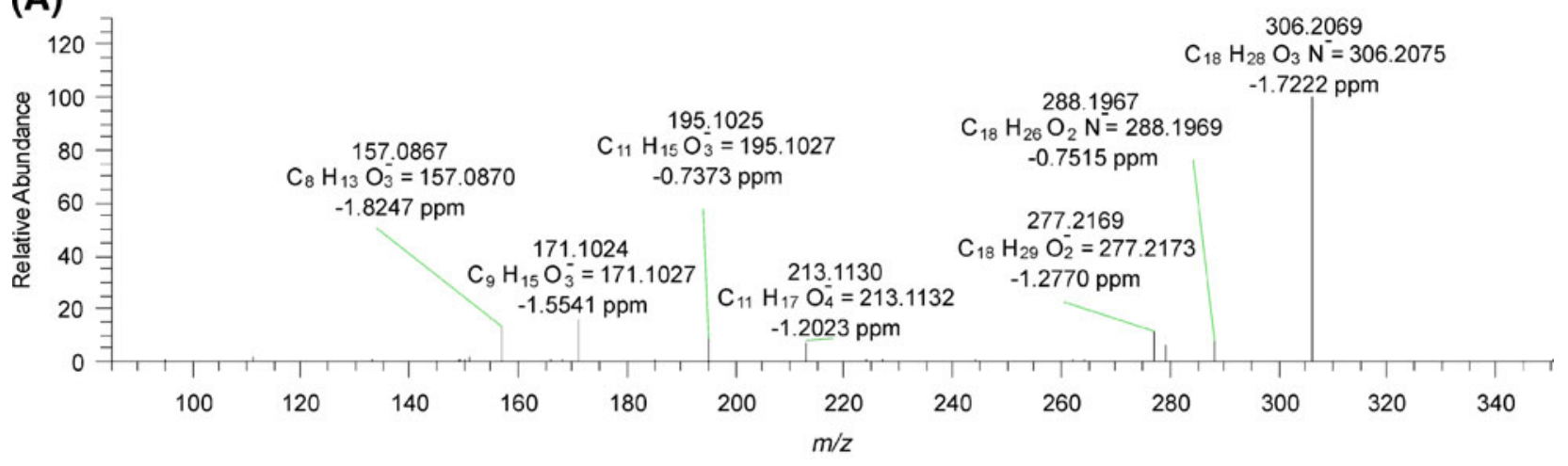

(B)

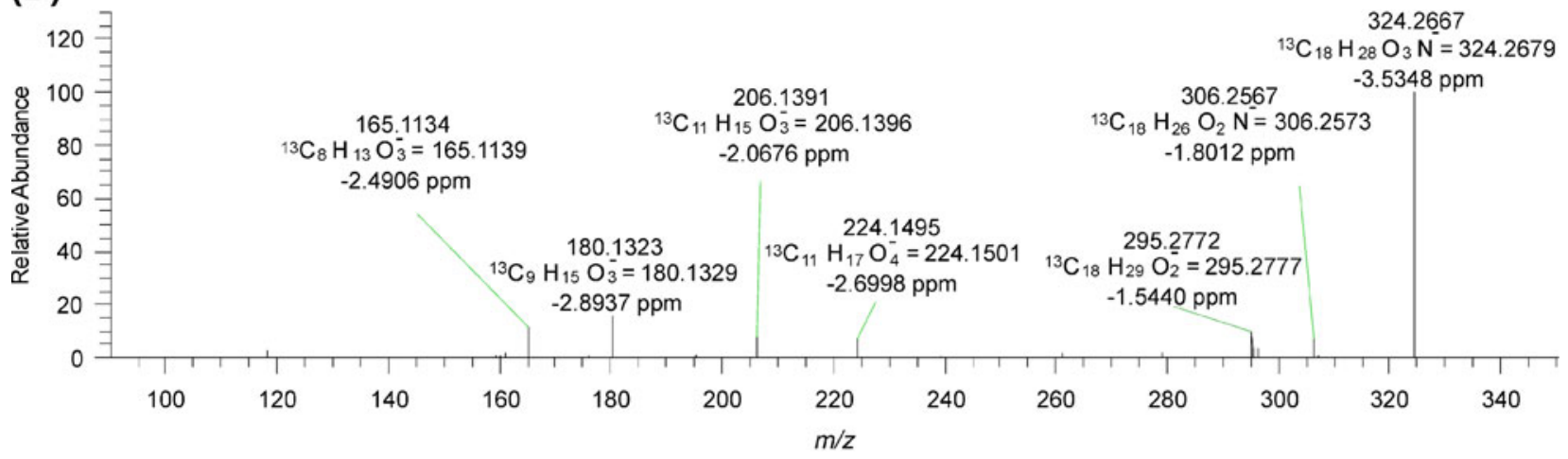

(C)

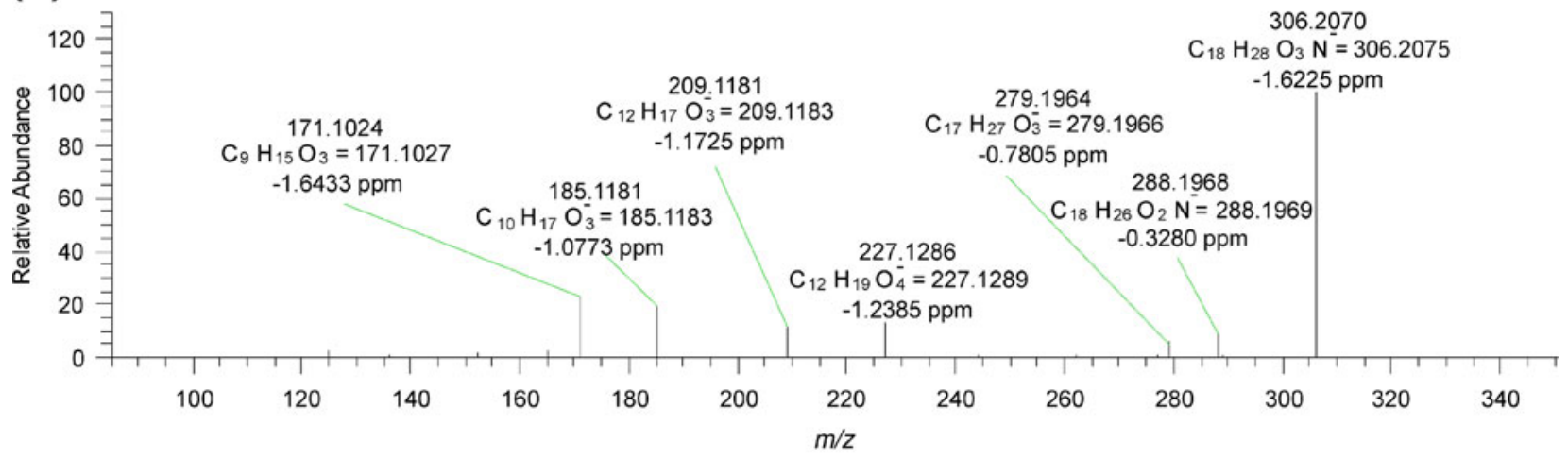

(D)

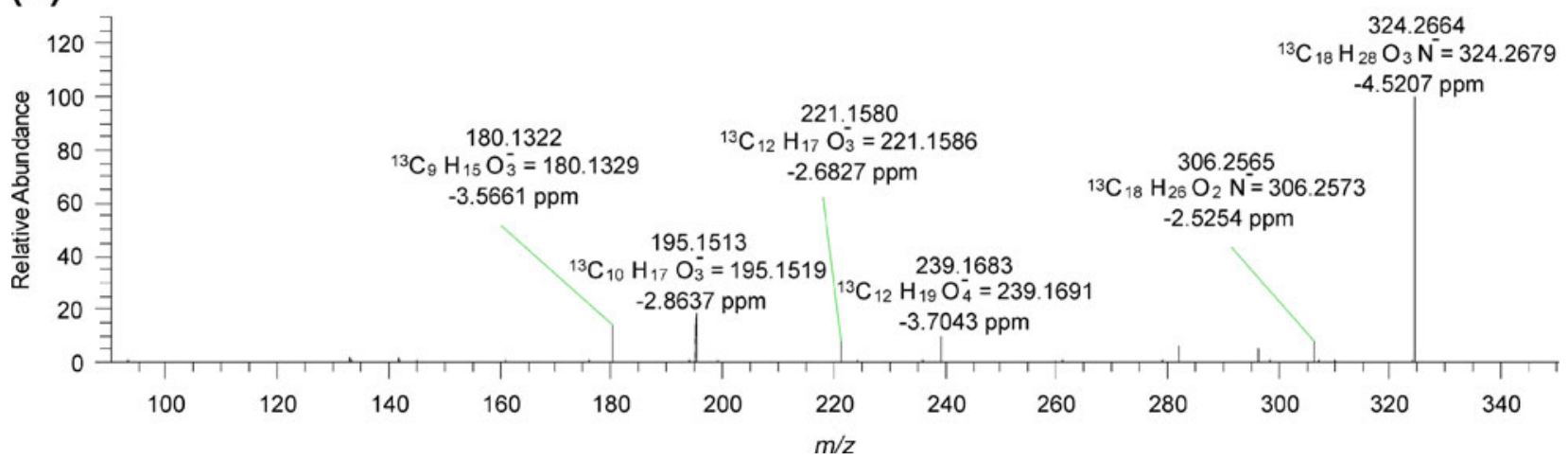

Figure 3. Product ion spectra of $[\mathrm{M}-\mathrm{H}]^{-}$ions of $\mathrm{m} / \mathrm{z} 324.2$ and 342.3 corresponding to $\mathrm{NO}_{2}-\mathrm{LA}$ and $\mathrm{NO}_{2}-\left[{ }^{13} \mathrm{C}_{18}\right] \mathrm{LA}$, respectively. (A) $12-\mathrm{NO}_{2}-\mathrm{LA},(\mathbf{B}) 12-\mathrm{NO}_{2}-\left[{ }^{13} \mathrm{C}_{18}\right] \mathrm{LA}$, (C) $13-\mathrm{NO}_{2}-\mathrm{LA}$, (D) $13-\mathrm{NO}_{2}-\left[{ }^{13} \mathrm{C}_{18}\right]$ LA recorded at a collision energy setting of $35 \mathrm{eV}$ using a hybrid FT mass spectrometer 
empirical approach [29]. From this preliminary energetic analysis, we discarded the structures having the greatest energies and performed high accuracy energy calculations using Gaussian 09 [30] on the two lowest energy structures (Scheme 4, ions 2 and 3, Table 1). We found that unsaturated imine 2 has a total energy $14.1 \mathrm{kcal} / \mathrm{mol}$ higher than nitrile 3. The product ion with lowest energy (3) was used as the endpoint product ion to define the fragmentation mechanism. Based on the initial structure, product ions, energetic analysis and fragmentation mechanisms, we propose for 3 a fragmentation pathway similar to an ozonolysis mechanism (Scheme 5). This is initiated by a
(A)
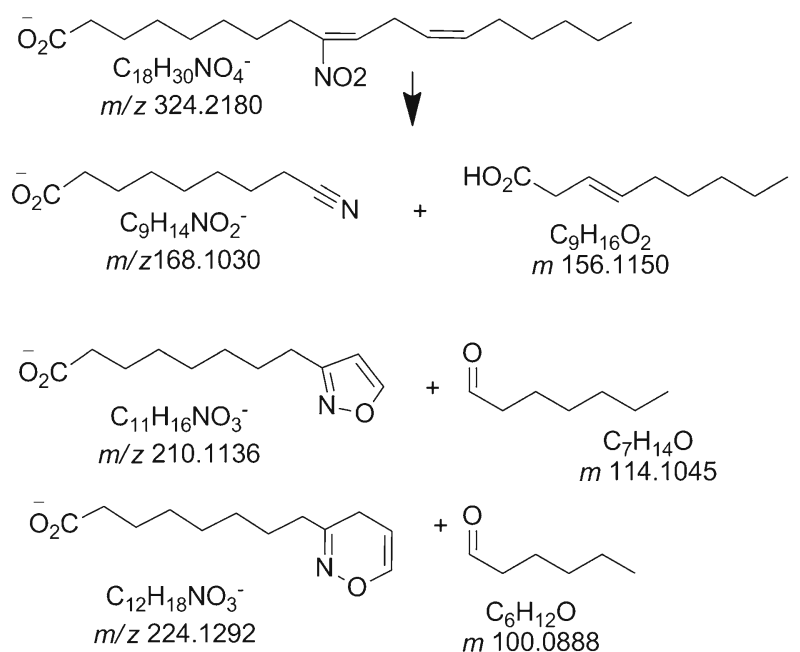

(B)
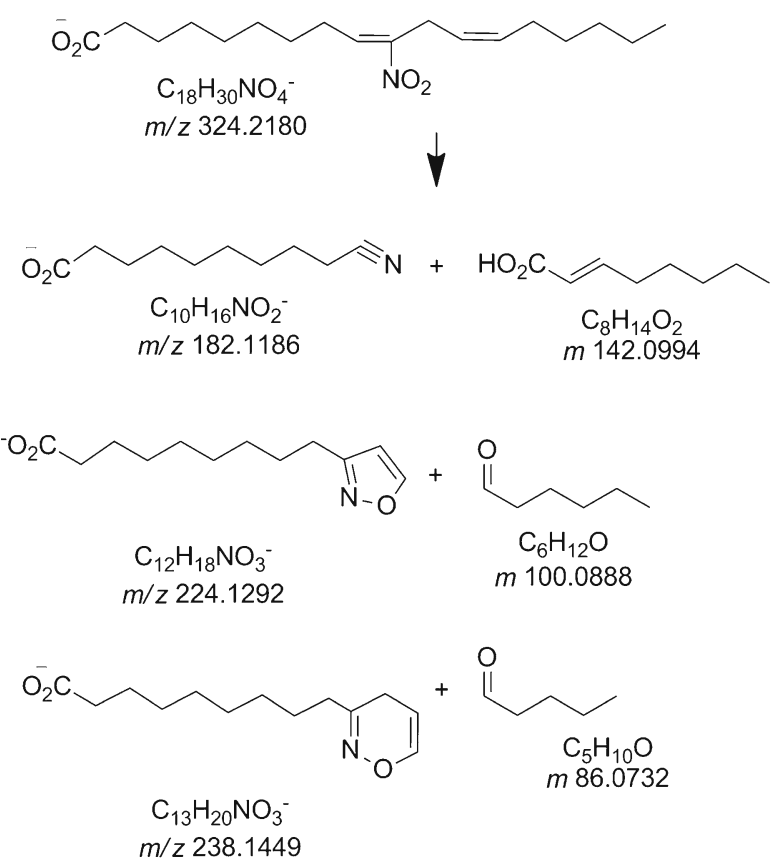

(C)

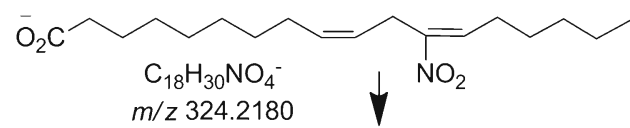

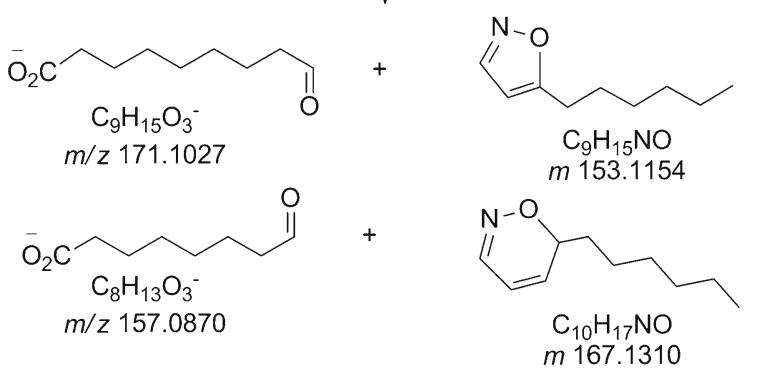

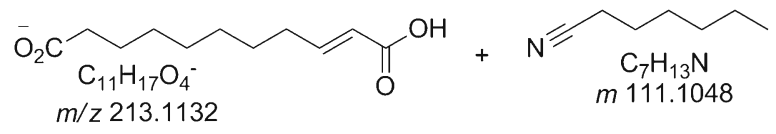

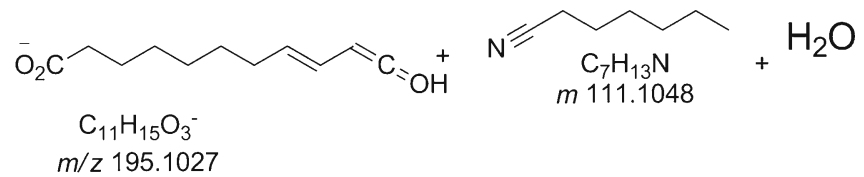

(D)<smiles></smiles>

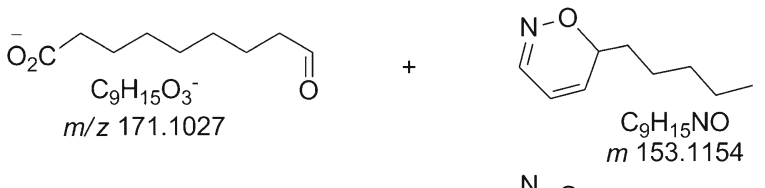

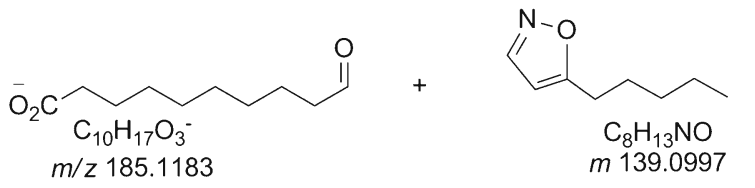

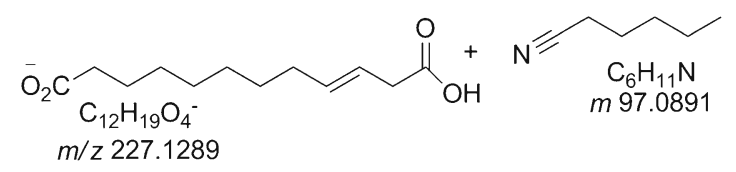<smiles>CCCCCC#N</smiles>

Scheme 3. Proposed product ions, containing structural information, and their respective neutral fragments of the gas phase fragmentation of 4 positional nitroalkene isomers. (A) 9- $\mathrm{NO}_{2}-\mathrm{LA}$, (B) 10- $\mathrm{NO}_{2}-\mathrm{LA}$, (C) 12- $\mathrm{NO}_{2}-\mathrm{LA},(\mathbf{D}) 13-\mathrm{NO}_{2}-\mathrm{LA}$ 


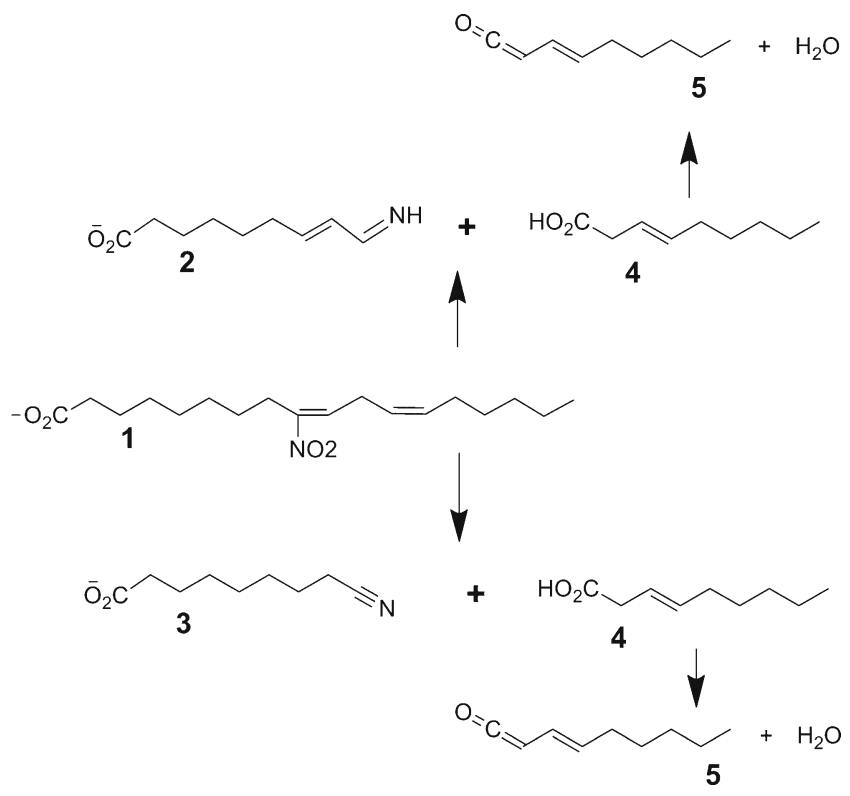

Scheme 4. Principal candidates of product ion and neutral losses obtained after fragmentation of $9-\mathrm{NO}_{2}-\mathrm{LA}$ to form a nitrile containing ion. lons 2 and 3 were selected for accurate free energy determinations because they displayed the lowest energies during semiempirical product ion calculations. Free energies are shown in Table 1. Ion 3 is the proposed ion products obtained during fragmentation

nitro-peroxynitroso rearrangement of the oxygen atoms on the nitro group to form the charged peroxynitroso species shown (again possibly via dioxaziridine rearrangement), followed by an intramolecular 1,3-cycloaddition on the neighboring carbon-carbon double bond to form the intermediate five-member ring 1,2,3-dioxazole (analogous to the well-known molozonide). This is followed by a posterior fragmentation by retro-1,3-cycloaddition of the 5 member ring (by analogy to the oxidative cleavage Criegee intermediate) to an aldehyde and a nitrile $N$-oxide. Upon relative rotation of the aldehyde and nitrile oxide to a preferable conformation, a second 1,3-cycloaddition generates a new five-member ring 1,4,2-dioxazole. Finally, a 1,2hydride shift concomitant with a last retro-1,3-cycloaddition forms a $\beta$-, $\gamma$-unsaturated nonenoic acid and a charged nitrile nonanoate (3), which is detected with a mass of $\mathrm{m} / \mathrm{z} 168.1$.

The ion at $\mathrm{m} / z 210.1$ (210.1132, molecular composition $\mathrm{C}_{11} \mathrm{H}_{16} \mathrm{O}_{3} \mathrm{~N}$ ) corresponds to a chain breakdown at the $\mathrm{C} 11-$ $\mathrm{C} 12$ bond with the generation of a five-member ring (isoxazole) product, while the product ion at $224.1 \mathrm{~m} / \mathrm{z}$ (224.1289, molecular composition $\mathrm{C}_{12} \mathrm{H}_{18} \mathrm{O}_{3} \mathrm{~N}$ ) represents a chain fragmentation at the $\mathrm{C} 12-\mathrm{C} 13$ bond along with the formation of a six-member heterocycle (4H-1,2-oxazine) (Schemes 3A, 6).

The fragmentation of the $9-\mathrm{NO}_{2}-\left[{ }^{13} \mathrm{C}_{18}\right]$ LA confirmed a product ion containing 9,11 , and 12 carbons corresponding to ions at $\mathrm{m} / \mathrm{z} 177.1$ (177.1326, molecular composition $\left.\left[{ }^{13} \mathrm{C}_{9} \mathrm{H}_{14} \mathrm{O}_{2} \mathrm{~N}\right]^{-}\right), 221.1$ (221.1505, molecular composition $\left.\left[{ }^{13} \mathrm{C}_{11} \mathrm{H}_{16} \mathrm{O}_{3} \mathrm{~N}\right]^{-}\right)$, and 236.1 (236.1688, molecular composi- tion $\left[{ }^{13} \mathrm{C}_{12} \mathrm{H}_{18} \mathrm{O}_{3} \mathrm{~N}\right]^{-}$), respectively (Figure $2 \mathrm{~B}$ ). For structural elucidation, a similar approach as for the $168.1 \mathrm{~m} / \mathrm{z}$ was used. Using the PM3 semiempirical method, energy values were calculated for several possible product structures associated with the $m / z 210.1$ ion (Supplementary Schemes 1 and 2). Fragments having lowest energies among each group were considered further. The ion product 7 shows the lowest energy $(12.3 \mathrm{kcal} / \mathrm{mol}$ lower than 6 , Table 1$)$. With regard to the non-charged product ions, density functional calculations reveal that Structure 8 (Scheme 6, Table 1) has the lowest energy, $9.3 \mathrm{kcal} / \mathrm{mol}$ and $11.9 \mathrm{kcal} / \mathrm{mol}$ lower than the other non-charged fragments tested ( 9 and 10, respectively). For this reason, we selected Structures 7 and 8 as the candidate product ions for which the fragmentation pathway is going to be elucidated. The proposed mechanism of fragmentation to form 7 and 8 is shown in Scheme 7. This involves an initial proton abstraction or transfer from the labile bisallylic methylene unit to the oxygens of the nitro, then a subsequent molecular internal rotation to realign the nitro group for an intramolecular 1,3-cycloaddition of the nitronate species onto the proximal carbon-carbon double bond ( $\beta, \gamma$ to the nitro) at the $\gamma$ position, generating the fivemember ring isoxalole-2-ol. A posterior retro Diels-Alder addition reaction (Scheme 7 sidebar) cleaves the final isoxazole $(\mathrm{m} / \mathrm{z}$ 210.1), while simultaneously forming the new $\sigma$ bond between the proximal alcohol and vinyl groups. This enol spontaneously generates an aldehyde after rapid keto-enol tautomerization to the thermodynamically-preferred isomer.

For the product ion $m / z$ 224.1, initial calculations (Supplementary Scheme 1) indicated that the structures with lower energies corresponded to 11 and 12 (Scheme 8). Accurate energy calculations confirmed semiempirical data showing that Structure 11 had the lowest energy, followed by Structure $12,9.6 \mathrm{kcal} / \mathrm{mol}$ greater. A fragmentation mechanism for product ion $224.1 \mathrm{~m} / \mathrm{z}$ is presented in

Table 1. Total and relative energies for the 15 tested structures. Energies were calculated using the B3LYP method and 6-311G basis set. Zero point energy corrections were applied. The displayed $\Delta \mathrm{E}$ represents the energy difference compared to the structure with lowest energy value (assigned as $0)$ of each structural group. Groups are represented by Structures 2-3, 4-5, 6-7, 8-10, 11-12, and 13-15

\begin{tabular}{ccc} 
Structure & Electronic + thermal energy at $298 \mathrm{~K}(\mathrm{kcal} / \mathrm{mol})$ & $\Delta \mathrm{E}(\mathrm{kcal} / \mathrm{mol})$ \\
\hline 2 & -349121.24 & 16.1 \\
3 & -349137.30 & 0 \\
4 & -315491.38 & 0 \\
5 & -267529.07 & 47962.3 \\
6 & -444844.96 & 12.3 \\
7 & -444857.24 & 0 \\
8 & -195089.64 & 0 \\
9 & -195080.37 & 9.3 \\
10 & -195077.75 & 11.9 \\
11 & -469491.61 & 0 \\
12 & -469481.97 & 9.6 \\
13 & -219739.58 & 0 \\
14 & -219730.34 & 9.2 \\
15 & -219727.71 & 11.9 \\
\hline
\end{tabular}




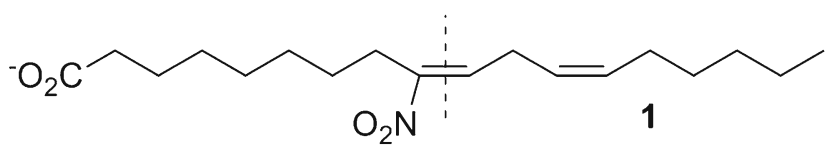<smiles>CCCCC/C=C/C/C=C(\CCCCCCCC(=O)[O-])[N+](=O)[O-]</smiles>

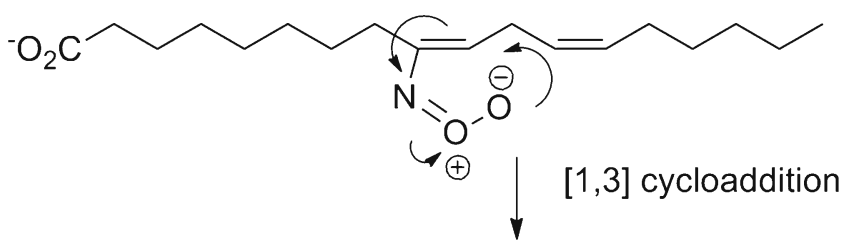

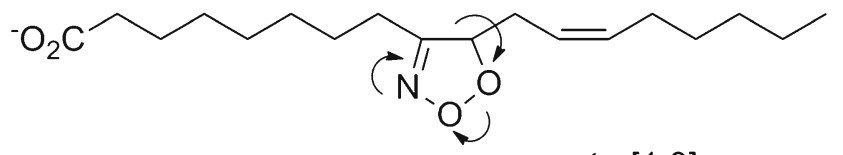

retro[1,3]-<smiles>CCCCC/C=C\CC1(C(=O)C=O)CCCC1</smiles>

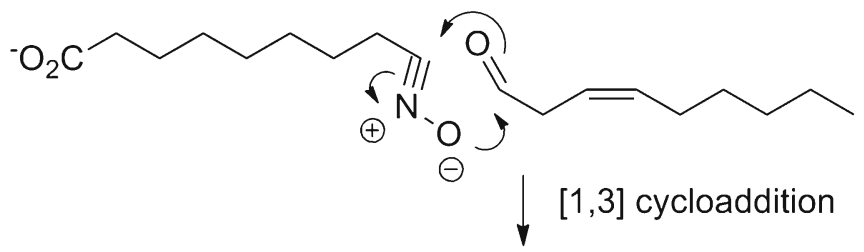

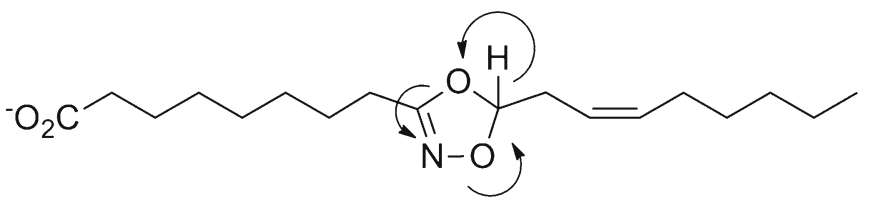

$[1,2] \mathrm{H}$ - shift retro $[1,3]$<smiles>N#CCCCCCCCC(=O)[O-]</smiles>

3<smiles>CCCCC/C=C/CC(=O)O</smiles>

Scheme 5. Proposed fragmentation pathway of $9-\mathrm{NO}_{2}$-LA. Product ion 3 and neutral loss 4 were selected because they display the lowest free energy

Scheme 9. The initial intramolecular 1,3-cycloaddition is followed by a retro 1,3-cycloaddition, which forms an aldehyde and a hexacyclic ylide $(\mathrm{m} / \mathrm{z} 224.1)$ that is further stabilized by a proton transfer and tautomerization to a more stable 4H-1,2-oxazine. Evidently, the relative placement of the nitro group and alkene are sufficiently distant, and the carbon chain sufficiently flexible, for these intramolecular additions to proceed. Note also the low energy differences 


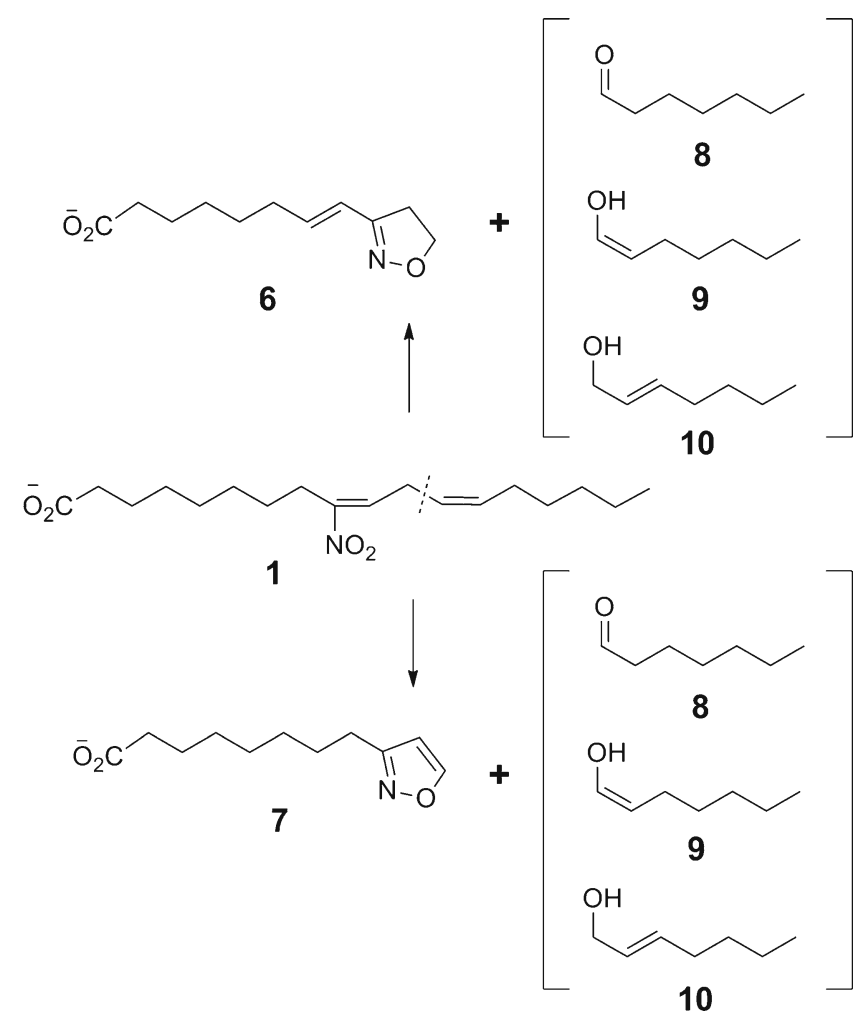

Scheme 6. Main candidates of product ion and neutral losses obtained after fragmentation of $9-\mathrm{NO}_{2}-\mathrm{LA}$ to form a five-member heterocycle. Ions 6 and 7 were selected for accurate free energy determinations because they displayed the lowest energies during semiempirical product ion calculations. Free energies are shown in Table 1. Ion 7 is the proposed ion products obtained during fragmentation in addition to the neutral fragment 8

calculated between the oxazine isomers. A summary of the structures of the product ions for $9-\mathrm{NO}_{2}-\mathrm{LA}$ is shown in Scheme 3 A.

10-NO$-\mathrm{NO}_{2}-\mathbf{L A}$ : The CID fragmentation of $10-\mathrm{NO}_{2}-\mathrm{LA}$ gave three characteristic ions with $\mathrm{m} / \mathrm{z}$ values of 182.1, 224.1, and 238.1 (Figure 2C, Scheme 3B), thus showing an overall average shift of 14.0154 with respect to the $9-\mathrm{NO}_{2}-\mathrm{LA}$ that corresponds to a methylene group (14.01510). These three ions contain relevant structural information and their molecular composition is consistent with 10, 12, and 13 carbon, respectively, as confirmed by accurate mass determination. Analysis of $10-\mathrm{NO}_{2}-\left[{ }^{13} \mathrm{C}_{18}\right] \mathrm{LA}$ showed the expected fragments corresponding to ions with masses 192.1, 236.1, and 251.1 (Figure 2D), further confirming the molecular compositions. Moreover, this indicates that the fragmentation pathways occur analogously in the 1,4skipped diene whether the nitro group is located at $\alpha-, \beta-$; $\delta$-, $\varepsilon-$ (exterior, e.g., 9-NO $\mathrm{NO}_{2} \mathrm{LA}$ ) as well as at $\alpha-, \beta-; \gamma-, \delta$ (interior, e.g., 10- $\mathrm{NO}_{2}$-LA) relative positions in the 1,4skipped diene motif with respect to the $\mathrm{NO}_{2}$ group, resulting in products with an additional methylene group. No space charge constraints affecting the proposed fragmentation mechanism were observed when $9-\mathrm{NO}_{2}-$ and $10-\mathrm{NO}_{2}-\mathrm{LA}$ regioisomers were compared.

12- $\mathrm{NO}_{2}-\mathbf{L A}$ : It was hypothesized that both 12- and 13$\mathrm{NO}_{2}$-LA would fragment following the same mechanisms described for the $9-\mathrm{NO}_{2}-$ and $10-\mathrm{NO}_{2}-\mathrm{LA}$ regioisomers. Thus, analysis of product ions would aid in the structural characterization of the neutral fragments arising from the fragmentation of $9-\mathrm{NO}_{2}$ - and $10-\mathrm{NO}_{2}-\mathrm{LA}$, based on the fact that in all cases, the charge remains locked at the carboxylate anion terminus and that these molecules have interior relative symmetric structures with regard to nitro and alkene locations. Energy calculations for the neutral fragmentation products were already performed for $9-\mathrm{NO}_{2}-\mathrm{LA}$ (Schemes 4, 6, and 8, Supplementary Scheme 2, Table 1). For the 12$\mathrm{NO}_{2}$-LA regioisomer, the masses of the ions containing structural information were determined to be 157.1, 171.1, 195.1, and 213.1 (Figure 3A). Accurate mass determination revealed the presence of $8,9,11$, and 11 carbons, respectively. The use of a ${ }^{13} \mathrm{C}$ standard $\left(12-\mathrm{NO}_{2}-\left[{ }^{13} \mathrm{C}_{18}\right]\right.$ LA) confirmed the molecular composition for ion products $m / z 165.1,180.1,206.1$ and 224.1, respectively (Figure 3B). Loss of $\mathrm{CO}_{2}$ was observed for these ion products upon $\mathrm{MS}^{3}$ analysis. Thus, the analysis of $12-\mathrm{NO}_{2}-\mathrm{LA}$ corroborates the proposed neutral products depicted in the fragmentation schemes for 9- $\mathrm{NO}_{2}-\mathrm{LA}$ and $10-\mathrm{NO}_{2}$-LA (Scheme 3).

Notably, the methylene-interrupted diene resulted in the formation and detection of two fragments containing either a carboxylic acid or an aldehyde, with the latter most likely derived from the carboxylic group by a loss of $\mathrm{H}_{2} \mathrm{O}$. However, the fragmentation of the $10-\mathrm{NO}_{2}-\mathrm{OA}$ only exhibited the formation of the aldehyde $(\mathrm{m} / \mathrm{z} 169.1)$, suggesting that the additional exocyclic double bond on the carbon chain may favor the recyclization step (step 5, Scheme 5) or impair the formation of a reactive carbonyl peroxide upon fragmentation (step 3, Scheme 2).

13-NO2-LA: The characteristic ions containing structural information of $13-\mathrm{NO}_{2}-\mathrm{LA}$ were identified with masses 171.1, 185.1, 227.1, and 209.1 (Figure 3C). Accurate mass determinations $(<3 \mathrm{ppm})$ revealed the presence of $9,10,12$, and 12 carbons, respectively. The molecular composition of these product ions was further confirmed by the analysis of a ${ }^{13} \mathrm{C}$ standard $\left(13-\mathrm{NO}_{2}-\left[{ }^{13} \mathrm{C}_{18}\right] \mathrm{LA}\right)$, which showed the expected ions at $m / z 180.1,195.1,239.2$, and 221.2, respectively (Figure 3D). The fragmentation mechanism confirms the formation of five- and six-member heterocyclic rings and the formation of a carboxylic acid and an aldehyde upon fragmentation of the carbon chain. The 227.1 ion contains a carboxylic acid moiety that undergoes rapid dehydration, with the subsequent formation of a ketenyl terminus $\left(m / z\right.$ 209.1). The fragmentation of $13-\mathrm{NO}_{2}-\mathrm{LA}$ revealed a similar fragmentation pattern as observed for 12 - 

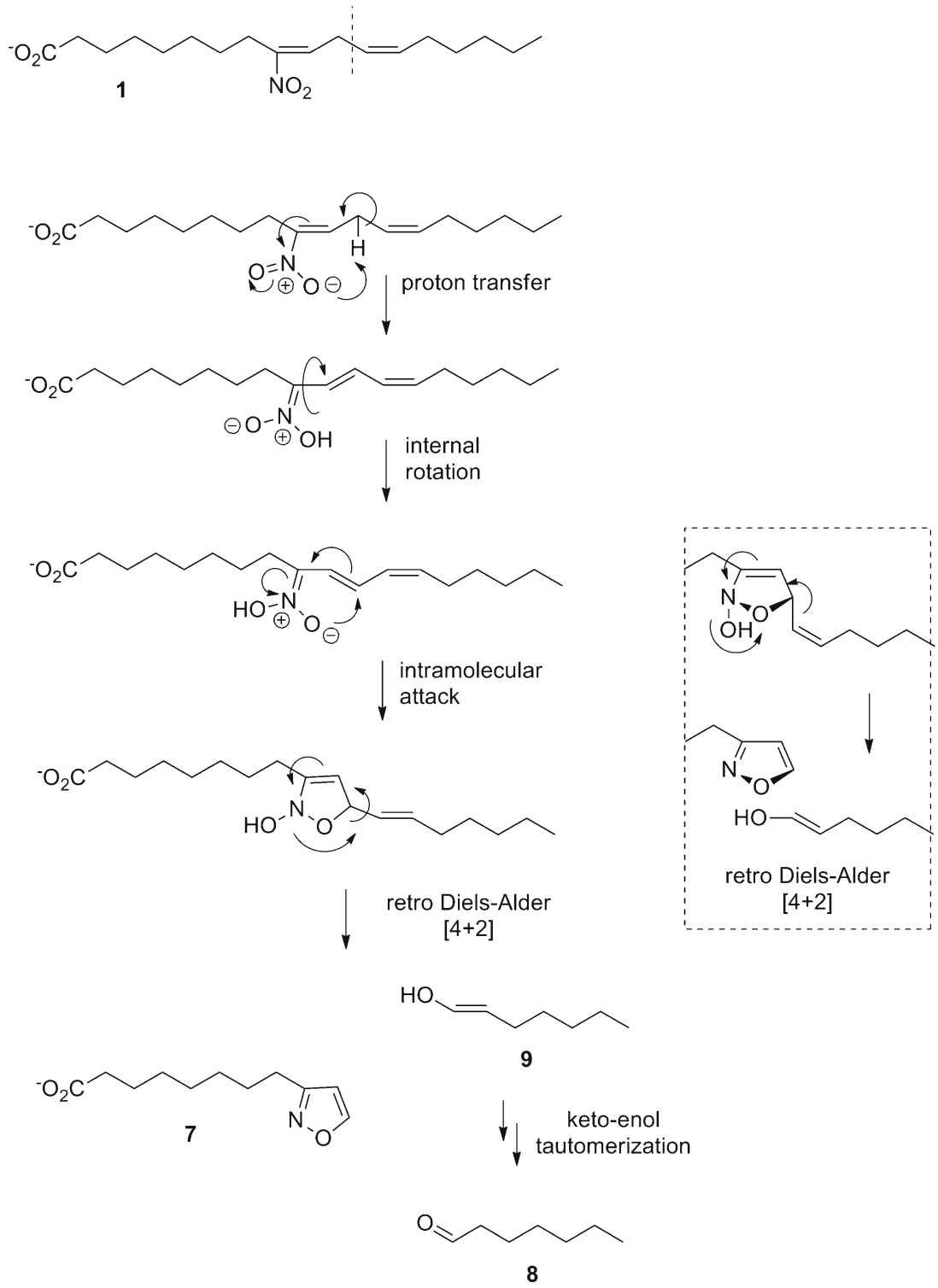

Scheme 7. Proposed fragmentation pathway of $9-\mathrm{NO}_{2}-\mathrm{LA}$ to form the pentacycle containing product ion. Product ion 7 and neutral loss 8 displayed the lowest free energy compared with other products

$\mathrm{NO}_{2}$-LA, indicating that no conformational constraints affect the fragmentation pattern.

\section{Fragmentation of ${ }^{15} \mathrm{NO}_{2}-\mathrm{LA}$}

To gain further insight and confirmation of the fragmentation mechanism of $\mathrm{NO}_{2}$-LA, the four isomers of ${ }^{15} \mathrm{~N}$ containing $\mathrm{NO}_{2}$-LA were fragmented and analyzed using high resolution mass spectrometry. All three major product ions having structural information for $9-\mathrm{NO}_{2}-\mathrm{LA}(\mathrm{m} / \mathrm{z}$ $168.1,210.1$ and 224.1) contain a nitrogen atom as evidenced by the shift in 1 Da observed upon $9-{ }^{15} \mathrm{NO}_{2}$ LA fragmentation (yielding product ions with $\mathrm{m} / \mathrm{z}$ 169.1, 211.1 and 225.1; Figure 4A). Similarly, the fragmentation of $10-{ }^{15} \mathrm{NO}_{2}$-LA (Figure 4B) resulted in a shift of product ions of 14 with respect to $9-{ }^{15} \mathrm{NO}_{2}$-LA (Figure 4A) and in a shift of 1 Da with respect of the fragments observed when $10-\mathrm{NO}_{2}-\mathrm{LA}$ was analyzed (Figure 2). These data confirm the fragments obtained and the presence of nitrogen in the product ions upon fragmentation in the 9- and $10-\mathrm{NO}_{2}-\mathrm{LA}$ isomers.

High resolution analysis of $12-$ and $13-\mathrm{NO}_{2}-\mathrm{LA}$ product ions did not provide evidence of the presence of nitrogen in the proposed structures (Figure 3 ). This was confirmed by fragmentation of $12-$ and $13-{ }^{15} \mathrm{NO}_{2}-\mathrm{LA}$ (Figure 4C, D), which did not show a shift in the molecular mass of the chain breaking product ions with respect to 12 - and $13-\mathrm{NO}_{2}-\mathrm{LA}$. Thus, both $12-{ }^{15} \mathrm{NO}_{2}-\mathrm{LA}$ and $12-\mathrm{NO}_{2}$-LA shared the same $157.1,171.1,195.1$, and $213.1 \mathrm{~m} / \mathrm{z}$ diagnostic ions and $13-{ }^{15} \mathrm{NO}_{2}-\mathrm{LA}$ and $13-\mathrm{NO}_{2}-$ LA shared the same 171.1, 185.1, 209.1, and $227.1 \mathrm{~m} / \mathrm{z}$ diagnostic ions. 


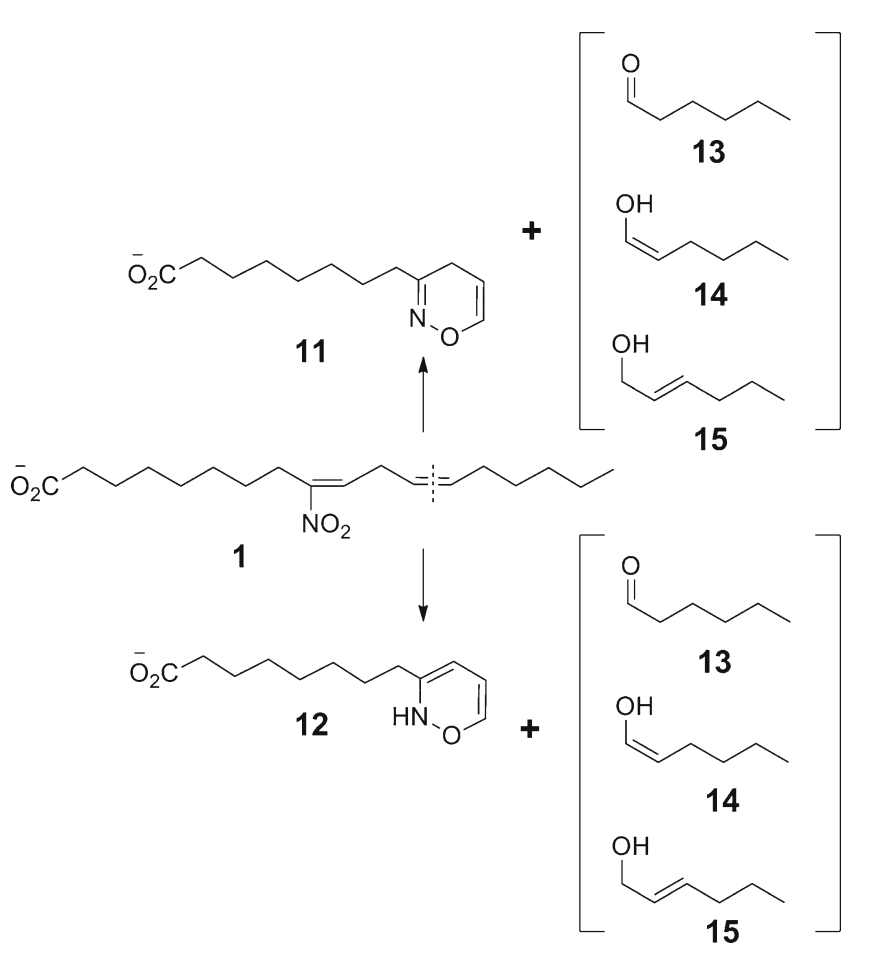

Scheme 8. Main candidates for product ion and neutral losses obtained after fragmentation of $9-\mathrm{NO}_{2}$-LA to form a hexacycle. lons 11 and 12 were selected from accurate free energy determinations because they displayed the lowest energies during semiempirical product ion calculations. Free energies are shown in Table 1. Ion 11 is the proposed ion products obtained during fragmentation in addition to the neutral fragment 13. Neutral fragment 13 is a methylene group shorter than neutral ion 8 formed during fragmentation rendering the five-member heterocycle

\section{$\mathrm{NO}_{2}-\mathrm{SA}$ and Reduced $\mathrm{NO}_{2}-\mathrm{LA}$}

The presence of the nitroalkene was necessary to provide the electron density needed for net oxygen transfers to the carbon $\beta$ to the nitro. Moreover, an additional double bond in the molecule allows an alternative pathway characterized by multiple cyclization pathways and the formation of stable five- or sixmember rings. The fragmentation pathways of a bis-allylic interrupted nitroalkane-alkene were then tested. In this case, the electron density of the alkene was present but no double bond conjugation (nitroalkene) was available to accept the concerted flow of electrons necessary for intramolecular cyclization and oxygen transfer reactions. In this regard, CID fragmentation exhibited a major loss of $47 \mathrm{Da}$ (neutral loss of $\mathrm{HNO}_{2}$ ), a product ion of $46 \mathrm{~m} / \mathrm{z}\left(\mathrm{NO}_{2}^{-}\right)$and almost no other product ions (Figure 5A). The fragmentation closely resembled the fragments obtained by SA-NO ${ }_{2}$, in which a major loss of $\mathrm{HNO}_{2}$ or formation of $\mathrm{NO}_{2}^{-}$was observed (Figure 5B, C, Supplementary Scheme 3). Finally, it became clear that the unsaturation found in nitroalkenes is a necessary requirement for the observed fragmentation pathways. Moreover, the presence of an electronrich double bond in the $\gamma$ - or $\delta$ - positions with respect to the $\mathrm{NO}_{2}$ group did not modify the fragmentation products of nitro-
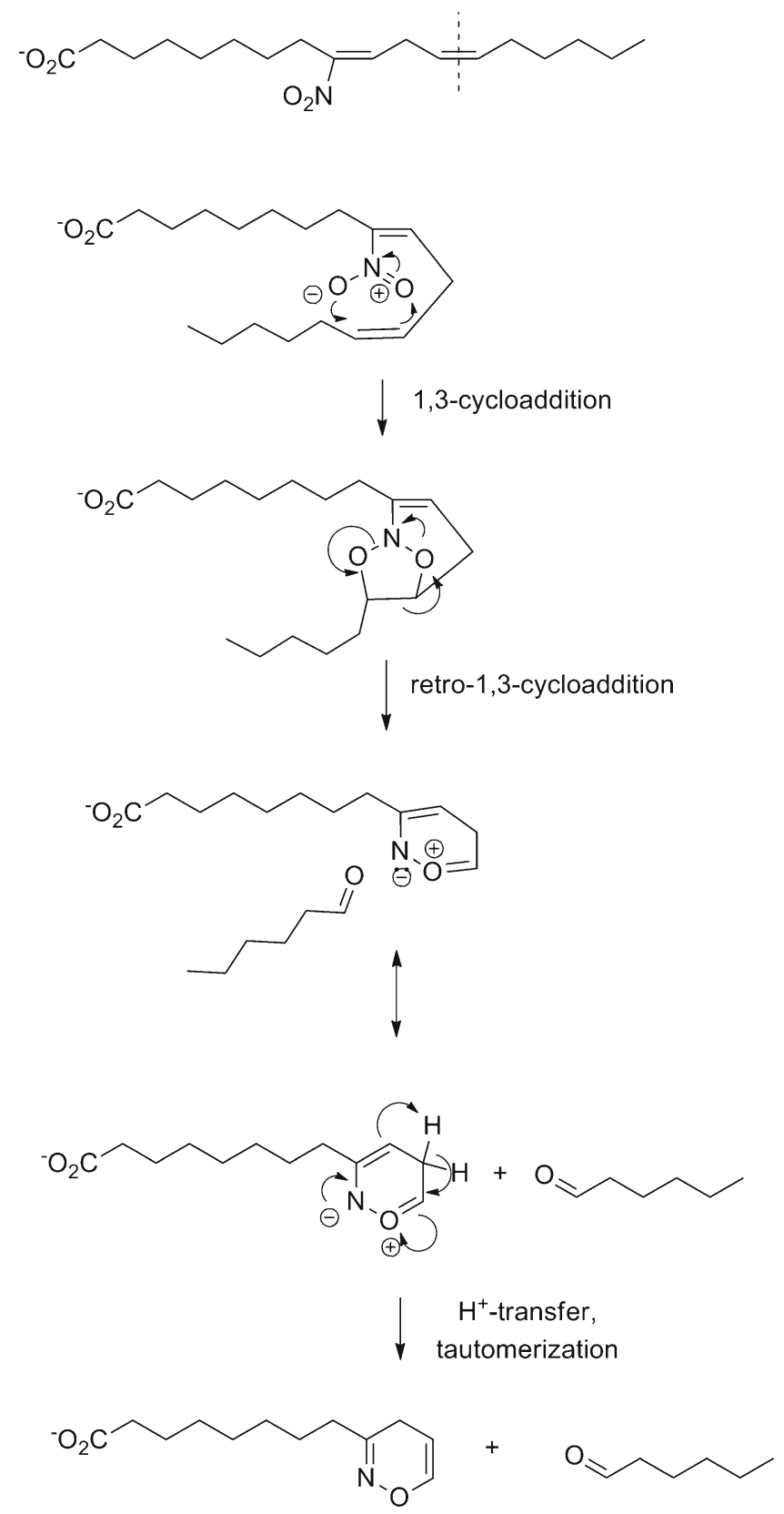

Scheme 9. Proposed fragmentation pathway of $9-\mathrm{NO}_{2}-\mathrm{LA}$ to form the hexacyclic product ion. Product ion 11 and neutral loss 13 displayed the lowest free energy compared with other possible products

alkanes, thus demonstrating that the highly electron-withdrawn $\pi$ electrons of the nitroalkene double bond $\left(\alpha, \beta\right.$ - to the $\mathrm{NO}_{2}$ group) actively participate in the oxygen transfer.

\section{Fragmentation Yield Efficiencies for Specific Product Ions}

The translation of this analysis into structural characterization for confirmation of biological $\mathrm{NO}_{2}$-FA unknowns depends on the yields obtained during the fragmentation of the specific product ions. The slopes obtained for the $\mathrm{m} / \mathrm{z}$ 
(A)

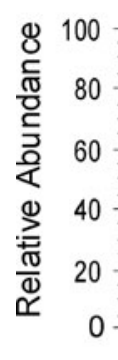

211.1106

$\mathrm{C}_{11} \mathrm{H}_{16} \mathrm{O}_{3}{ }^{15} \mathrm{~N}=211.1106$

$-0.1521 \mathrm{ppm}$

289.1939

$\mathrm{C}_{18} \mathrm{H}_{26} \mathrm{O}_{2}{ }^{15} \mathrm{~N}^{-}=289.1939$

$-0.0709 \mathrm{ppm}$ $\mathrm{C}_{18} \mathrm{H}_{28} \mathrm{O}_{3} 15 \mathrm{~N}^{-}=307.2045$ $-0.6325 \mathrm{ppm}$

\subsection{3}

$\mathrm{C}_{18} \mathrm{H}_{29} \mathrm{O}_{2}^{-}=277.2173$

$\mathrm{C}_{12} \mathrm{H}_{18} \mathrm{O}_{3}{ }^{15} \mathrm{~N}=225.1263$

$\mathrm{C}_{9} \mathrm{H}_{14} \mathrm{O}_{2}{ }^{15} \mathrm{~N}^{-}=169.1000$

$-0.2100 \mathrm{ppm}$

$0.1485 \mathrm{ppm}$

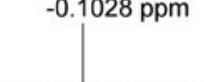

$m / 2$

(B)

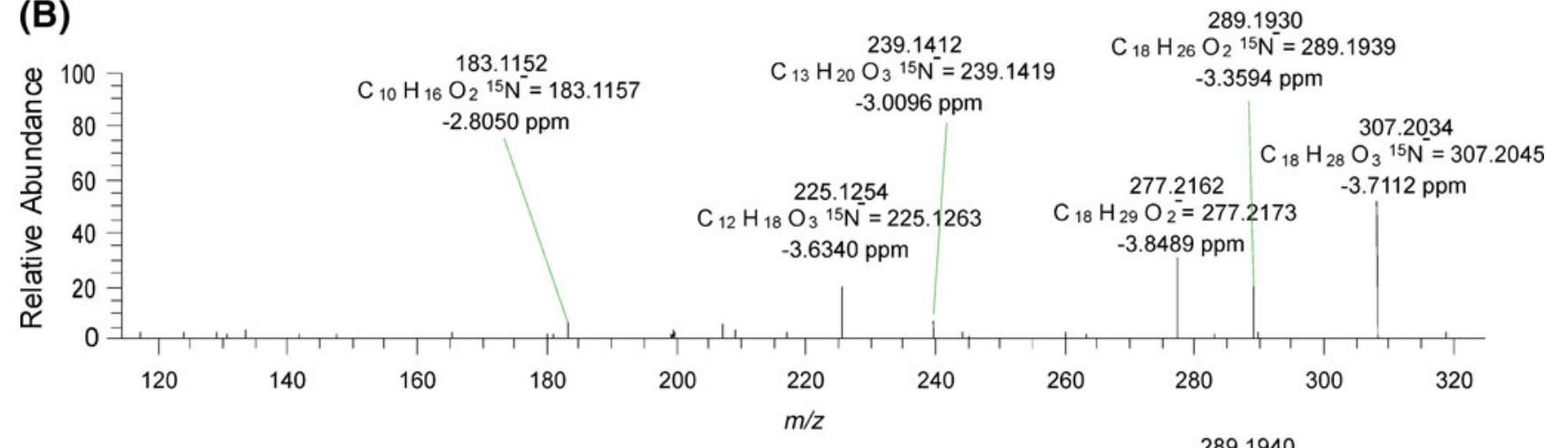

$\mathrm{m} / \mathrm{z}$

(C)

을

20

160

180

200

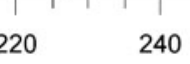

260

280

$300 \quad 320$

$/ 2$

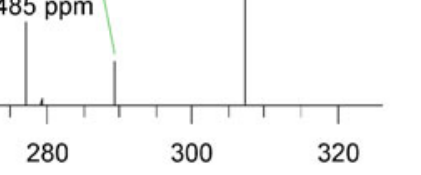

289.1930

$\mathrm{O}_{2} 15 \mathrm{~N}=289.1939$

$\mathrm{O}_{3}{ }^{15} \mathrm{~N}=239.1419 \quad-3.3594 \mathrm{ppm}$

289.1940

$\begin{array}{ccc} & 171.1027 & 195.1027 \\ 100 & \mathrm{C}_{9} \mathrm{H}_{15} \mathrm{O}_{3}^{-}=171.1027 & \mathrm{C}_{11} \mathrm{H}_{15} \mathrm{O}_{3}^{-}=195.1027 \\ 0.0209 \mathrm{ppm} & 0.2651 \mathrm{ppm}\end{array}$

$\mathrm{C}_{18} \mathrm{H}_{26} \mathrm{O}_{2}{ }^{15} \mathrm{~N}^{-}=289.1939$

$0.1688 \mathrm{ppm}$

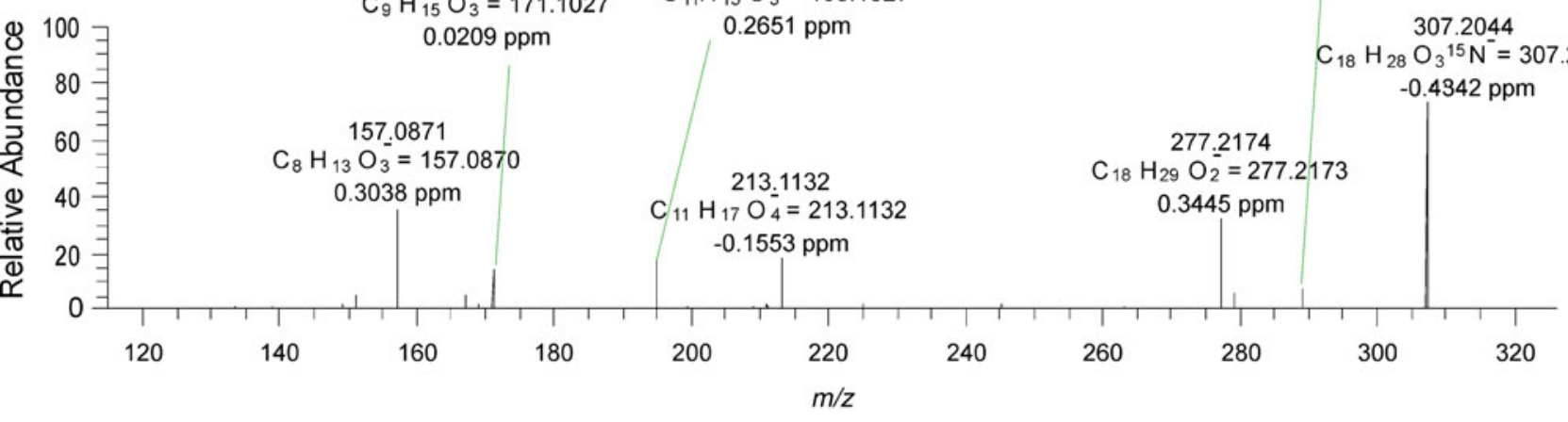

(D)

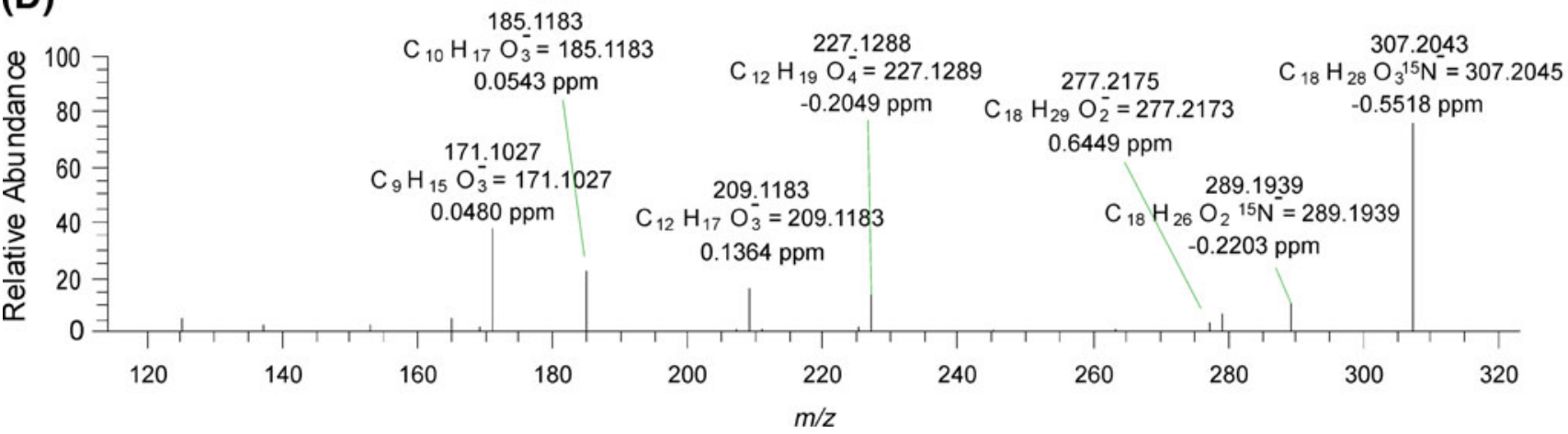

Figure 4. Product ion spectra of $[\mathrm{M}-\mathrm{H}]-$ ions of $m / z 325.3$ corresponding to ${ }^{15} \mathrm{NO}_{2}$-LA. (A) $9-{ }^{15} \mathrm{NO}_{2}-\mathrm{LA}$, (B) $10-{ }^{15} \mathrm{NO}_{2}-\mathrm{LA},(\mathbf{C})$ $12-{ }^{15} \mathrm{NO}_{2}$-LA, (D) $13-{ }^{15} \mathrm{NO}_{2}$-LA recorded at a collision energy setting of $35 \mathrm{eV}$ using a hybrid FT mass spectrometer 

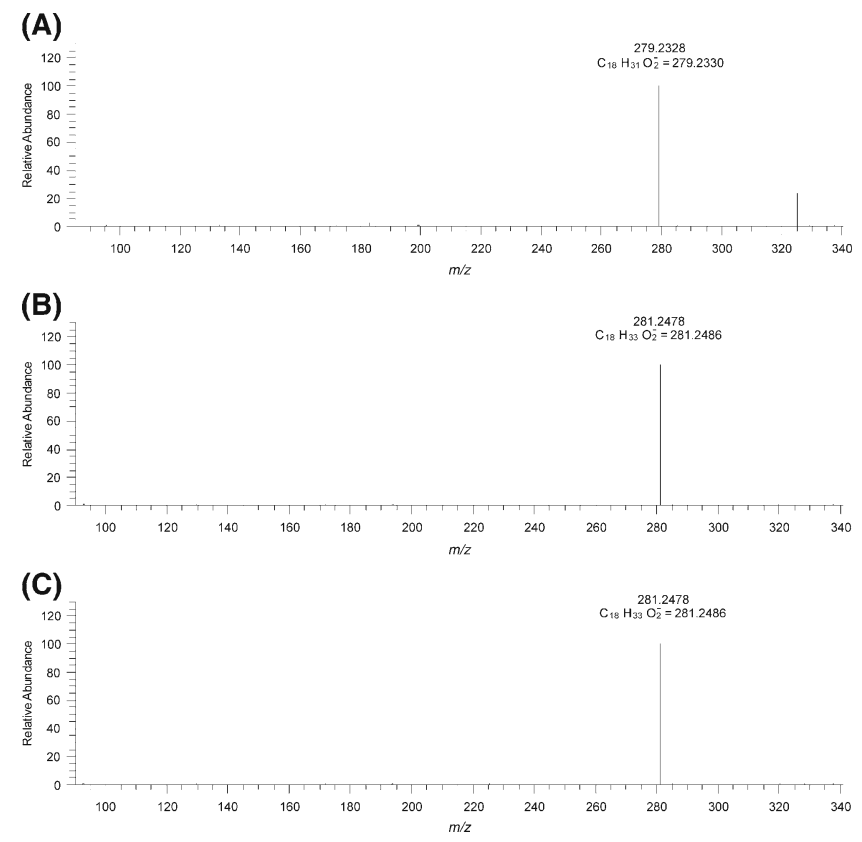

Figure 5. Product ion spectra of $[\mathrm{M}-\mathrm{H}]^{-}$ions of $\mathrm{m} / \mathrm{z} 326.3$ and 328.3 corresponding to reduced $\mathrm{NO}_{2}$-LA (nitroalkane alkene containing $\mathrm{NO}_{2}-\mathrm{OA}$ ) and reduced $\mathrm{NO}_{2}-\mathrm{OA}$ (nitrostearic acid, SA$\mathrm{NO}_{2}$ ) respectively. (A) reduced $\mathrm{NO}_{2}-\mathrm{LA}\left(\mathrm{m} / \mathrm{z}\right.$ 326.3), (B) $10-\mathrm{NO}_{2}-$ $\mathrm{SA}\left(\mathrm{m} / z\right.$ 328.3), (C) $9-\mathrm{NO}_{2}-\mathrm{SA}(\mathrm{m} / z$ 328.3) recorded at a collision energy setting of $35 \mathrm{eV}$ using a hybrid FT mass spectrometer

Table 2. Efficiency of MRM specific transitions for $\mathrm{LA}-\mathrm{NO}_{2}$ and $\mathrm{OA}-\mathrm{NO}_{2}$. The efficiency is expressed relative to the maximum signal obtained, which corresponds to the fragmentation following the formation of the $\mathrm{NO}_{2}{ }^{-}$ product ion $\left(324.2 \rightarrow 46\right.$ and $326.2 \rightarrow 46$ for $\mathrm{LA}-\mathrm{NO}_{2}$ and $\mathrm{OA}-\mathrm{NO}_{2}$, respectively)

\begin{tabular}{lc}
\hline MRM transition & Product ion efficiency $(\%)$ \\
\hline $9-\mathrm{NO}_{2}$-LA & \\
$324.2 \rightarrow 46$ & 100 \\
$324.2 \rightarrow 168.1$ & 7.9 \\
$324.2 \rightarrow 210.1$ & 1.5 \\
$324.2 \rightarrow 224.1$ & 3.3 \\
$10-\mathrm{NO}_{2}$-LA & 100 \\
$324.2 \rightarrow 46$ & 1.3 \\
$324.2 \rightarrow 182.1$ & 3.3 \\
$324.2 \rightarrow 224.1$ & 0.2 \\
$324.2 \rightarrow 238.1$ & \\
$12-\mathrm{NO}_{2}$-LA & 100 \\
$324.2 \rightarrow 46$ & 7.3 \\
$324.2 \rightarrow 157.1$ & 14.2 \\
$324.2 \rightarrow 171.1$ & 1.4 \\
$324.2 \rightarrow 195.1$ & 0.8 \\
$324.2 \rightarrow 213.1$ & 100 \\
$13-\mathrm{NO}_{2}$-LA & 14.1 \\
$324.2 \rightarrow 46$ & 8.2 \\
$324.2 \rightarrow 171.1$ & 4.8 \\
$324.2 \rightarrow 185.1$ & 2.8 \\
$324.2 \rightarrow 209.1$ & 100 \\
$324.2 \rightarrow 227.1$ & 4.6 \\
$9-\mathrm{NO}_{2}$-OA & 100 \\
$326.2 \rightarrow 46$ & 2.0 \\
$326.2 \rightarrow 168.1$ & \\
$10-\mathrm{NO}_{2}$-OA & \\
$324.2 \rightarrow 46$ & \\
$326.2 \rightarrow 169.1$ & \\
\hline &
\end{tabular}

$324.2 \rightarrow 46$ standard curve for the four different $\mathrm{NO}_{2}$-LA isomers were 1 , representing a $100 \%$. The data reported in Table 2 indicate efficiency yields (represented by the slopes of the standard curves with respect to the $324.2 \rightarrow 46$ transition) for specific product ions of up to $14 \%$. Notably, the limit of detection (LOD), necessary to establish identity of the different isomers, was between 1.2 and 5 times the calculated limit of quantification (LOQ) values for the highest product ion containing structural information for each isomer, further supporting both the theoretical and biological value of the method.

\section{Conclusions}

By evaluating the gas phase fragmentation products of nitroalkane and nitroalkene containing fatty acids, we propose several fragmentation pathways. These mechanisms provide the necessary elements for more insightful characterization of this class of labile and readily metabolized inflammatory signaling mediators. It has been previously observed that saturated aliphatic carbon chains containing nitro groups fragment via $\mathrm{NO}_{2}^{-}$losses or $\mathrm{HNO}_{2}$ neutral losses, rendering fragments with no structural information. Notably, the presence of a nitroalkene strongly favors both chain breaking fragmentation mechanisms as well as $\mathrm{H}_{2} \mathrm{O}$, $\mathrm{HNO}_{2}$ and $\mathrm{NO}_{2}{ }^{-}$losses [23]. The $\mathrm{H}_{2} \mathrm{O}$ loss occurs at the $\mathrm{NO}_{2}$ group, while the carboxylic acid retains the charge through the fragmentation process. In the case of monounsaturated nitroalkene fatty acids, the fragmentation mechanism involves an initial rearrangement followed by a retrocycloaddition and rupture to form fragments containing nitrile and aldehyde moieties. In particular, ions with $\mathrm{m} / \mathrm{z}$ 168.1 and 169.1 indicate the presence of a double bond at position $\mathrm{C} 9$ and $\mathrm{NO}_{2}$ groups at $\mathrm{C} 9$ and $\mathrm{C} 10$, respectively.

An unsaturation at positions $\delta$ - or $\gamma$ - to the $\mathrm{NO}_{2}$ group of the nitroalkene in polyunsaturated nitro fatty acids results in three major chain fragmentation pathways. These include nitrile and aldehyde products, as observed for monounsaturated nitroalkenes, and five- and six-member ring heterocycles. Several steps are involved in the formation of these species. In particular, fragmentation of $9-\mathrm{NO}_{2}$-LA results in specific ion fragments with $\mathrm{m} / \mathrm{z}$ of $168.1,210.1$, and 224.1 with the latter showing a shift in $14 \mathrm{Da}$ and having five- and six-member rings. The $10-\mathrm{NO}_{2}-\mathrm{LA}$ presented an overall shift of $14 \mathrm{Da}$ compared with the fragments obtained from $9-\mathrm{NO}_{2}-\mathrm{LA}$. The fragmentation of $12-\mathrm{NO}_{2}$-LA resulted in a different set of charged product ions characterized by $\mathrm{m} / \mathrm{z}$ of $157.1,171.1$, 213.1, and 195.1. The difference in 14 Da between ions with $\mathrm{m} / \mathrm{z}$ of 157.1 and 171.1 corresponds to the neutral formation of six- and five-member heterocycles (as observed for 9- and 10$\mathrm{NO}_{2}$-LA isomers). Finally, the fragmentation of $13-\mathrm{NO}_{2}-\mathrm{LA}$ shows an overall shift of $14 \mathrm{Da}$ compared with $12-\mathrm{NO}_{2}-\mathrm{LA}$ with characteristic $\mathrm{m} / \mathrm{z}$ of $171.1,185.1,227.1$, and 209.1 .

The efficiency of these product ions is between $0.2 \%$ and $14 \%$ of the maximal fragmentation obtained when following the formation of a 46 product ion $\left(\mathrm{NO}_{2}{ }^{-}\right)$. The LOD of these 
fragments is between 1.2 and 5 times the LOQ, underlining the potential and applicability of this technique to the analysis of isomers in biological samples.

\section{Acknowledgments}

The authors thank Paul R. S. Baker, Ph.D. for useful discussions. This study was supported by an USPHS grant R01DA027806 and a Department of Education grant P116Z090309 (to E.K.A.), a Junior Faculty Award 7-08JF-52 American Diabetes Association (to F.J.S.), and R01 HL58115 and R01 HL64937 (to B.A.F., F.J.S.).

\section{References}

1. O'Donnell, V.B., Eiserich, J.P., Chumley, P.H., Jablonsky, M.J., Krishna, N.R., Kirk, M., Barnes, S., Darley-Usmar, V.M., Freeman, B.A.: Nitration of Unsaturated Fatty Acids by Nitric Oxide-Derived Reactive Nitrogen Species Peroxynitrite, Nitrous Acid, Nitrogen Dioxide, and Nitronium ion. Chem. Res. Toxicol. 12, 83-92 (1999)

2. Rubbo, H., Parthasarathy, S., Barnes, S., Kirk, M., Kalyanaraman, B., Freeman, B.A.: Nitric Oxide Inhibition of Lipoxygenase-Dependent Liposome and Low-Density Lipoprotein Oxidation: Termination of Radical Chain Propagation Reactions and Formation of NitrogenContaining Oxidized Lipid Derivatives. Arch. Biochem. Biophys. 324, 15-25 (1995)

3. Baker, P.R., Lin, Y., Schopfer, F.J., Woodcock, S.R., Groeger, A.L., Batthyany, C., Sweeney, S., Long, M.H., Iles, K.E., Baker, L.M., Branchaud, B.P., Chen, Y.E., Freeman, B.A.: Fatty Acid Transduction of Nitric Oxide Signaling: Multiple Nitrated Unsaturated Fatty Acid Derivatives Exist in Human Blood and Urine and Serve as Endogenous Peroxisome Proliferator-Activated Receptor Ligands. J Biol. Chem. 280, 42464-42475 (2005)

4. Baker, P.R., Schopfer, F.J., Sweeney, S., Freeman, B.A.: Red Cell Membrane and Plasma Linoleic Acid Nitration Products: Synthesis, Clinical Identification, and Quantitation. Proc. Natl. Acad. Sci. USA 101, 11577-11582 (2004)

5. Lima, E.S., Di Mascio, P., Abdalla, D.S.: Cholesteryl Nitrolinoleate, a Nitrated Lipid Present in Human Blood Plasma and Lipoproteins. $J$. Lipid Res. 44, 1660-1666 (2003)

6. Rudolph, V., Rudolph, T.K., Schopfer, F.J., Bonacci, G., Woodcock, S. R., Cole, M.P., Baker, P.R., Ramani, R., Freeman, B.A.: Endogenous Generation and Protective Effects of Nitro-Fatty Acids in a Murine Model of Focal Cardiac Ischemia and Reperfusion. Cardiovasc. Res. 85, 155-166 (2010)

7. Tsikas, D., Zoerner, A., Mitschke, A., Homsi, Y., Gutzki, F.M., Jordan, J.: Specific GC-MS/MS Stable-Isotope Dilution Methodology for Free 9- and 10-Nitro-Oleic Acid in Human Plasma Challenges Previous LCMS/MS Reports. J. Chromatogr. B Analyt. Technol. Biomed. Life Sci. 877, 2895-2908 (2009)

8. Tsikas, D., Zoerner, A.A., Mitschke, A., Gutzki, F.M.: Nitro-Fatty Acids Occur in Human Plasma in the Picomolar Range: A Targeted Nitro-Lipidomics GC-MS/MS Study. Lipids 44, 855-865 (2009)

9. Schopfer, F.J., Lin, Y., Baker, P.R., Cui, T., Garcia-Barrio, M., Zhang, J., Chen, K., Chen, Y.E., Freeman, B.A.: Nitrolinoleic Acid: An Endogenous Peroxisome Proliferator-Activated Receptor $\gamma$ ligand. Proc. Natl. Acad. Sci. USA 102, 2340-2345 (2005)

10. Kansanen, E., Jyrkkanen, H.K., Volger, O.L., Leinonen, H., Kivela, A.M., Hakkinen, S.K., Woodcock, S.R., Schopfer, F.J., Horrevoets, A.J., YlaHerttuala, S., Freeman, B.A., Levonen, A.L.: Nrf2-Dependent and Independent Responses to Nitro-Fatty Acids in Human Endothelial Cells: Identification of Heat Shock Response as the Major Pathway Activated by Nitro-Oleic Acid. J. Biol. Chem. 284, 33233-33241 (2009)

11. Cui, T., Schopfer, F.J., Zhang, J., Chen, K., Ichikawa, T., Baker, P.R., Batthyany, C., Chacko, B.K., Feng, X., Patel, R.P., Agarwal, A., Freeman, B.A., Chen, Y.E.: Nitrated Fatty Acids: Endogenous AntiInflammatory Signaling mediators. J. Biol. Chem. 281, 35686-35698 (2006)

12. Liu, W., Morrow, J.D., Yin, H.: Quantification of F2-Isoprostanes as a Reliable Index of Oxidative Stress In Vivo Using Gas Chromatography-
Mass Spectrometry (GC-MS) Method. Free Radic. Biol. Med. 47, 1101-1107 (2009)

13. Nadtochiy, S.M., Baker, P.R., Freeman, B.A., Brookes, P.S.: Mitochondrial Nitroalkene Formation and Mild Uncoupling in Ischaemic Preconditioning: Implications for Cardioprotection. Cardiovasc. Res. 82, 333-340 (2009)

14. Rudolph, V., Schopfer, F.J., Khoo, N.K., Rudolph, T.K., Cole, M.P., Woodcock, S.R., Bonacci, G., Groeger, A.L., Golin-Bisello, F., Chen, C.S., Baker, P.R., Freeman, B.A.: Nitro-Fatty Acid Metabolome: Saturation, Desaturation, $\beta$-Oxidation, and Protein Adduction. J. Biol. Chem. 284, 1461-1473 (2009)

15. Baker, L.M., Baker, P.R., Golin-Bisello, F., Schopfer, F.J., Fink, M., Woodcock, S.R., Branchaud, B.P., Radi, R., Freeman, B.A.: NitroFatty Acid Reaction with Glutathione and Cysteine. Kinetic Analysis of Thiol Alkylation by a Michael Addition Reaction. J. Biol. Chem. 282, 31085-31093 (2007)

16. Ferreira, A.M., Ferrari, M.I., Trostchansky, A., Batthyany, C., Souza, J. M., Alvarez, M.N., Lopez, G.V., Baker, P.R., Schopfer, F.J., O'Donnell, V., Freeman, B.A., Rubbo, H.: Macrophage Activation Induces Formation of the Anti-Inflammatory Lipid Cholesteryl-Nitrolinoleate. Biochem. J. 417, 223-234 (2009)

17. Ferreira, A.M., Trostchansky, A., Ferrari, M., Souza, J.M., Rubbo, H.: Nitroalkenes: Synthesis, Characterization, and Effects on Macrophage Activation. Methods Enzymol. 441, 33-51 (2008)

18. Kelley, E.E., Batthyany, C.I., Hundley, N.J., Woodcock, S.R., Bonacci, G., Del Rio, J.M., Schopfer, F.J., Lancaster Jr., J.R., Freeman, B.A., Tarpey, M.M.: Nitro-Oleic Acid, a Novel and Irreversible Inhibitor of Xanthine Oxidoreductase. J. Biol. Chem. 283, 36176-36184 (2008)

19. Batthyany, C., Schopfer, F.J., Baker, P.R., Duran, R., Baker, L.M., Huang, Y., Cervenansky, C., Branchaud, B.P., Freeman, B.A.: Reversible Post-Translational Modification of Proteins by Nitrated Fatty Acids In Vivo. J. Biol. Chem. 281, 20450-20463 (2006)

20. Gorczynski, M.J., Smitherman, P.K., Akiyama, T.E., Wood, H.B., Berger, J.P., King, S.B., Morrow, C.S.: Activation of Peroxisome Proliferator-Activated Receptor $\gamma$ (PPAR $\gamma$ ) by Nitroalkene Fatty Acids: Importance of Nitration Position and Degree of Unsaturation. J. Med. Chem. 52, 4631-4639 (2009)

21. Li, Y., Zhang, J., Schopfer, F.J., Martynowski, D., Garcia-Barrio, M.T., Kovach, A., Suino-Powell, K., Baker, P.R., Freeman, B.A., Chen, Y.E., $\mathrm{Xu}$, H.E.: Molecular Recognition of Nitrated Fatty Acids by PPAR $\gamma$. Nat. Struct. Mol. Biol. 15, 865-867 (2008)

22. Balazy, M., Iesaki, T., Park, J.L., Jiang, H., Kaminski, P.M., Wolin, M. S.: Vicinal Nitrohydroxyeicosatrienoic Acids: Vasodilator Lipids Formed by Reaction of Nitrogen Dioxide with Arachidonic acid. $J$. Pharmacol. Exp. Ther. 299, 611-619 (2001)

23. Jain, K., Siddam, A., Marathi, A., Roy, U., Falck, J.R., Balazy, M.: The Mechanism of Oleic Acid Nitration by *NO(2). Free Radic. Biol. Med. 45, 269-283 (2008)

24. Trostchansky, A., Souza, J.M., Ferreira, A., Ferrari, M., Blanco, F., Trujillo, M., Castro, D., Cerecetto, H., Baker, P.R., O'Donnell, V.B., Rubbo, H.: Synthesis, Isomer Characterization, and Anti-Inflammatory Properties of Nitroarachidonate. Biochemistry 46, 4645-4653 (2007)

25. Attygalle, A.B., Ruzicka, J., Varughese, D., Bialecki, J.B., Jafri, S.: Low-energy collision-induced fragmentation of negative ions derived from ortho-, meta-, and para-hydroxyphenyl carbaldehydes, ketones, and related compounds. J. Mass Spectrom. 42, 1207-1217 (2007)

26. Schymanski, E.L., Meringer, M., Brack, W.: Matching Structures to Mass Spectra Using Fragmentation Patterns: Are the Results as Good as They Look? Anal. Chem. 81, 3608-3617 (2009)

27. Woodcock, S.R., Marwitz, A.J.V., Bruno, P., Branchaud, B.P.: Synthesis of Nitrolipids. All Four Possible Diastereomers of Nitrooleic Acids: (E)- and (Z)-, 9-, and 10-Nitro-Octadec-9-Enoic Acids. Org. Lett. 8, 3931-3934 (2006)

28. MOE, Chemical Computing Group, Inc.: Montreal.

29. Stewart, J.P.: Optimization of Parameters for Semiempirical Methods I. Method. J. Comp. Chem. 10, 209-220 (1989)

30. Frisch, M.J.T.G.W., Schlegel, H.B., Scuseria, G.E., Robb, M.A., Cheeseman, J.R., Scalmani, G., Barone, V., Mennucci, B., Petersson, G.A., Nakatsuji, H., Caricato, M., Li, X., Hratchian, H.P., Izmaylov, A. F., Bloino, J., Zheng, G., Sonnenberg, J.L., Hada, M., Ehara, M., Toyota, K., Fukuda, R., Hasegawa, J., Ishida, M., Nakajima, T., Honda, Y., Kitao, O., Nakai, H., Vreven, T., Montgomery, J.A. Jr., Peralta, J.E., Ogliaro, F., Bearpark, M., Heyd, J.J., Brothers, E., Kudin, K.N., Staroverov, V.N., Kobayashi, R., Normand, J., Raghavachari, K., 
Rendell, A., Burant, J.C., Iyengar, S.S., Tomasi, J., Cossi, M., Rega, N., Millam, N.J., Klene, M., Knox, J.E., Cross, J.B., Bakken, V., Adamo, C., Jaramillo, J., Gomperts, R., Stratmann, R.E., Yazyev, O., Austin, A. J., Cammi, R., Pomelli, C., Ochterski, J.W., Martin, R.L., Morokuma, K., Zakrzewski, V.G., Voth, G.A., Salvador, P., Dannenberg, J.J., Dapprich, S., Daniels, A.D., Farkas, Ö., Foresman, J.B., Ortiz, J.V., Cioslowski, J., Fox, D.J.: Gaussian 09, Revision, Gaussian, Inc.: (2009)

31. Schopfer, F.J., Batthyany, C., Baker, P.R., Bonacci, G., Cole, M.P., Rudolph, V., Groeger, A.L., Rudolph, T.K., Nadtochiy, S., Brookes,
P.S., Freeman, B.A.: Detection and Quantification of Protein Adduction by Electrophilic Fatty Acids: Mitochondrial Generation of Fatty Acid Nitroalkene Derivatives. Free Radic. Biol. Med. 46, 1250-1259 (2009)

32. Alexander, R.L., Wright, M.W., Gorczynski, M.J., Smitherman, P. K., Akiyama, T.E., Wood, H.B., Berger, J.P., King, S.B., Morrow, C.S.: Differential Potencies of Naturally Occurring Regioisomers of Nitrolinoleic Acid in PPAR $\gamma$ activation. Biochemistry 48, 492-498 (2009) 